\title{
Futures Made Present: Architecture, Monument, and the Battle for the 'Third Way' in Fascist Italy
}

\author{
Aristotle Kallis \\ Keele University \\ a.kallis@keele.ac.uk
}

\begin{abstract}
During the late 1920s and 1930s, a group of Italian modernist architects, known as 'rationalists', launched an ambitious bid for convincing Mussolini that their brand of architectural modernism was best suited to become the official art of the Fascist state (arte di stato). They produced buildings of exceptional quality and now iconic status in the annals of international architecture, as well as an even more impressive register of ideas, designs, plans, and proposals that have been recognized as visionary works. Yet, by the end of the 1930s, it was the official monumental stile littorio - classical and monumental yet abstracted and stripped-down, infused with modern and traditional ideas, pluralist and 'willing to seek a third way between opposite sides in disputes', the style curated so masterfully by Marcello Piacentini - that set the tone of the Fascist state's official architectural representation. These two contrasted architectural programmes, however, shared much more than what was claimed at the time and has been assumed since. They represented programmatically, ideologically, and aesthetically different expressions of the same profound desire to materialize in space and eternity the Fascist 'Third Way' future avant la lettre. In both cases, architecture (and urban planning as the scalable articulation of architecture on an urban, regional, and national territorial level) became the 'total' media used to signify and not just express, to shape and not just reproduce or simulate, to actively give before passively receiving meaning. Still, it was the more all-encompassing and legible coordinates of space and time in the 'rooted' modernism of the stile littorio that captured and expressed a third-way mediation between universality and singularity and between futural modernity and tradition better than the trenchant, inflexible anti-monumentalism of the rationalists.
\end{abstract}




\section{Keywords}

modernism - tradition - third way - piacentini - synthesis - rome - romanità

For a while at least in the lifespan of the Fascist regime in Italy, corporatism seemed to be the most dynamic and most alluring to its contemporaries element of the $F(f)$ ascist ideological singularity. It was lauded as an economic system that could reconcile competing interests in order to promote the kind of social harmony that capitalism had seemingly failed to deliver, and which socialism was programmatically opposed to. As an alternative system of political representation, it promised to overcome the crisis-ridden liberal parliamentary system while acting as an effective bulwark against the powerful aftershocks of the 1917 Bolshevik revolution in Russia. ${ }^{1}$ It is also not a coincidence that, when Mussolini finally decided that Italian Fascism was fit for 'export' as an alternative political paradigm to 'western' liberalism and 'eastern' communism, the most enthusiastic disciples of an international fascism in Italy rode the wave of corporatism, singing its praises as the genuine novelty of Mussolini's regime and dreaming of a 'Fascist century' with a Fascist and corporatist Italy as its principal innovation and symbolic ideological beacon. ${ }^{2}$

The popularity of the Fascist doctrine of corporatism lay to a crucial extent in its ability to communicate fascism as a genuine, exciting, and viable ideological alternative paradigm to liberalism and socialism. Still, this was an alternative rooted in a radical, perhaps even dissident synthesis of previously considered as incompatible ideas from left and right. An ideological late-comer in the crowded space of political ideologies, ${ }^{3}$ fascism operated as a "scavenger, moulding bits of old ideologies into a new whole". ${ }^{4}$ Thus fascism's ideological novelty lay in the radical re-combination and then radicalization of selected existing ideas. In so doing, fascism came to sponsor an ideological third way hostile to existing ideologies, hell-bent on overcoming them, but also offering an alternative that, however distinctly different and novel, still drew heavily

1 Antonio Costa Pinto, 'Fascism, Corporatism and the Crafting of Authoritarian Institutions in Interwar European Dictatorships,' in Rethinking Fascism and Dictatorship, ed. Antonio Costa Pinto and Aristotle Kallis (Basingstoke: Palgrave, 2014), 87-117.

2 Aristotle Kallis 'From CAUR to EUR: Italian Fascism, universalità, and the pursuit of international primacy,' Patterns of Prejudice 5, no. 4-5 (2016): 359-377.

3 Juan J. Linz, 'Political Space and Fascism as a Late-Comer,' in Who Were the Fascists: Social Roots of European Fascism, ed. Stein Ugelvik Larsen, Bernt Hagtvet, Jan Petter Myklebust (Oslo: Universitetsvorlaget, 1980), 153-189.

4 George L. Mosse, Masses and Man: Nationalist and Fascist Perceptions of Reality (Detroit: Wayne State University Press, 1980), 195. 
from the same contextual categories of liberalism and socialism that it so categorically rejected. ${ }^{5}$ Incubated in the deeply polarized ideological and political environment of post-wW1 Europe, fascism posited a stark contrast between a present-past of division, antagonism, and strife, on the one hand, and an attractive present-future of synthesis, harmony, and order, on the other hand.

This quest to emerge as a third way, all-embracing and all-conquering ideological platform was identified by George L Mosse as one of generic fascism's core definitional features. ${ }^{6}$ Roger Eatwell too saw fascist ideology as predicated on the quest for a holistic national-radical Third Way. ${ }^{7}$ The Third Way Fascism', Eatwell argued, 'is hostile to both capitalism and socialism, but draws on aspects of both. It sees capitalism as too individualistic, too dominated by the short run and ultimately not loyal to the community. It sees socialism as too internationalist and based on false views of equality. The exact nature of the Third Way can vary, though historically corporatism was its most common goal.'

MeanwhileZeevSternhell approached fascism as the product of a unique ideological synthesis of revolutionary left and nationalist right, of anti-Communist and anti-bourgeois thought, agitatory drive and order-preserving obsession. ${ }^{9}$ The hybrid of revolutionary ultra-nationalism, it seems, allowed fascism to claim the ideological equivalent of squaring the circle - a futural alternative vision based on a radical break with the past that nevertheless mined, subsumed, and valorized a new sense of tradition. Conversely, for Roger Griffin fascism qualifies as a third-way ideology primarily through its primary claim to "fight for a new vision ... pioneering a radical break with all traditional ideologies and parties".10 Thus it is important to map the fascist ideological 'third way' as both eclectic affinity with aspects of, and categorical rupture from, the conventional left-right, liberal/capitalist-socialist ideological schema. Synthesis did not preclude a new radical departure and direction of travel; but equally

Steve Bastow, James Martin, Third Way Discourse: European Ideologies in the Twentieth Century (Edinburgh: Edinburgh University Press, 2003), 22.

6 George L Mosse, The Fascist Revolution: Toward a General Theory of Fascism (New York: Fertig, 1999).

7 Roger Eatwell, 'Towards a New Model of Generic Fascism,' Journal of Theoretical Politics 4, no. 2 (1992): 161-194.

8 Roger Eatwell, 'On defining the "Fascist Minimum”: The centrality of ideology,' Journal of Political Ideologies 1, no. 3 (1996): 314.

9 Zeev Sternhell, Neither Right nor Left: Fascist Ideology in France (Princeton, NJ: Princeton University Press, 1994); Zeev Sternhell, The Birth of Fascist Ideology: From Cultural Rebellion to Political Revolution (Princeton NJ: Princeton University Press, 1994), 1-5. 
the distinct fascist third-way did not exist in an ideological, political, cultural or indeed historic vacuum.

The parabola of Fascist corporatism in the late 1920 s and early 1930s mirrored that of the distinctly Italian brand of modernist architecture called rationalism. In early 1931, the cultural critic Pier Maria Bardi and the architect Giuseppe Terragni called independently on Mussolini to elevate architecture to the status of the official art of the state (arte di stato)..1 These articles coincided with the peak of the culture wars at the heart of the Fascist regime: modernist versus traditional style, innovation and cosmopolitanism versus tradition and nationalism, city versus countryside. ${ }^{12}$ Each of the two authors spoke of the privileged relationship between modernist (and especially rationalist) architecture and Fascist politics, the former not simply representing, reproducing, and communicating Fascist ideas but also being capable of actively constructing a new, authentically Fascist political order.

It is not a coincidence that both Bardi and Terragni would soon afterwards be involved in a polemical conflation of their brand of modernist architecture with corporatism and Fascism as a whole. Through the pages of the architectural journal Quadrante that Bardi co-founded with Massimo Bontempelli in 1933, a coalition of Italian modernist architects agitated in favour of 'corporatism urbanism' (urbanistica corporativa). ${ }^{13}$ For them, corporatist urbanism unified the aesthetic and the cultural with the social and the political. In its utopian ambition to reshape the individual and society as a whole, a distinct idiom of modernist architecture and rational urban planning together sought to incarnate and simulate an ideal Fascist future based on a radical new relationship between individual, national society, and state. ${ }^{14}$

During the late 1920s and especially in the 1930s, Italian rationalist architects produced buildings of exceptional visionary and design quality, nowadays possessing iconic status in the annals of international architecture. They also generated an even more impressive register of ideas, designs, plans, and proposals that, albeit never realized, have been recognized as fiercely inventive works motivated by a passionate, utopian belief in the transformative role

\footnotetext{
11 Alberto Cuomo, Terragni Ultimo (Naples: Guida, 1987), 80.

12 Luciano Patetta, L'Architettura in Italia, 1919-1943: Le polemiche (Milan: Clup, 1972), 135-137.

13 David Rifkind, The Battle for Modernism: Quadrante and the Politicization of Architectural Discourse in Fascist Italy (Vicenza: Marsilio, 2012); Giuseppe Lupo, Sinisgalli e la cultura utopica degli anni Trenta (Milan: Vita e Pensiero, 1996), 114-120.

14 Jeffrey T. Schnapp, Building Fascism, Communism, Liberal Democracy: Gaetano Ciocca architect, Inventor, Farmer, Writer, Engineer (Stanford University Press, 2004), 75-76.
} 
of architecture and rational planning in modern society. ${ }^{15}$ Yet, hindsight leads us to the conclusion that Bardi's and Terragni's bid to anoint rationalist architecture as the 'art of the (Fascist) state' eventually failed. By the end of the 1930s, it was the official monumental stile littorio - classical yet stripped-down and abstracted, infused with modern and traditional ideas, inflected through international influences and local references, pluralist and "willing to seek a third way between opposite sides in disputes", the style curated so masterfully and consistently, but also flexibly by Marcello Piacentini - that set the tone of the Fascist state's official architectural representation. ${ }^{16}$ Piacentini's own architectural legacy remains fiercely debated, his attempt to synthesize and integrate styles and practitioners resulting in a hybrid idiom of official architecture that was as polarising at the time as it is now. ${ }^{17}$ Throughout the $1930 \mathrm{os}$, Piacentini was repeatedly criticized for being either too traditionalist, namely too rhetorical and wedded to a classically-inspired historicist monumentalism, or too modern and cosmopolitan, that is allegedly disrespectful of national and regional traditions. Undoubtedly some of his fiercest and most persistent critics came from within the ranks of the rationalists, with Bardi leading the chorus ever since the 1931 exhibition of rationalist architecture that he curated in Rome. The increasingly bitter campaign that rationalist architects and groupings waged against Piacentini may have referenced compositional and stylistic differences; but they were as much underpinned by an ideological and political divergence of opinion in regard to the future of Fascism per se. ${ }^{18}$

And yet, I argue, these two contrasted architectural visions shared the same ideological and political ambition - to simulate uniquely, authoritatively, and fully a perfect Fascist future, not just literally before the event but also avant la letter in its constitutive and discursive qualities - a 'future made present'. ${ }^{19}$

15 Aristotle Kallis, “'In miglior tempo...”: what fascism did not build in Rome,'Journal of Modern Italian Studies 16, no. 1 (2011): 59-83.

16 Harry Frances Malgrave, Modern Architectural Theory: A Historical Survey, 1673-1968 (Cambridge: Cambridge University Press, 2009), 311.

17 For an excellent, recent collection of perspectives on Piacentini see Giorgio Ciucci, Simonetta Lux and Franco Purini, ed., Marcello Piacentini Architetto, 1881-196o (Rome: Gangemi, 2012). This volume, derived from a conference that took place in Rome in 2010, contains a series of contributions debating the rich yet always controversial architectural legacy of Piacentini.

18 Paolo Melis, 'Piacentini e un padiglione per l'architettura a l'arte italiane all'Esposizione Internazionale di Parigi 1937,' in Marcello Piacentini architetto, ed. Giorgio Ciucci, Simonetta Lux and Franco Purini (Rome: Gangemi, 2012), 93-95.

19 Reinhart Koselleck, Futures Past: On the Semantics of Historical Time (New York: Columbia University Press, 2005), 259. 
In both cases, architecture (and urban planning as the scalable articulation of architecture on an urban, regional, and national territorial level) sought to imagine and shape before merely expressing, to signify before merely simulating, to actively give before passively receiving meaning. Invested in the utopia of a radical 'third way', architects sought to capture and perform a conclusive synthesis of opposed or fragmented energies of the past. A Fascist future, they felt, universal yet unmistakably Italian, had been rendered decisively close $(r)$, in the sense that the Fascist revolution had marked a radical departure and had unleashed a new temporality that allowed the gaze to reach beyond the horizon; but the precise shape of the future that lay beyond the horizon was still up for grabs. ${ }^{20}$

I argue that both the ambitious bid of the rationalists for the prize of official representation of Fascism, and its supersession by the circle of Piacentini and their stile littorio, emanated from the same utopian desire to erect monuments to their respective a priori vision of a 'third-way' Fascist future. Where the two visions diverged and clashed, however, was in their different understanding of monumentality as 'a structure which conveys the feeling of its eternity'. ${ }^{21}$ For most rationalists, monumentality as scale and ambition lay firmly in a universe of dismissive, angry rupture between the present and the future, not in the pursuit of a harmonious synthesis of experience and expectation. It was the intransigence of their vision of third way as rupture that alienated their architectural vision from the regime's pursuit of timeless universality during the first half of the 1930s. By contrast, what became known as the stile littorio sought to overcome the polarity of modernism-versus-tradition by positing a more open horizon of future change that remained rooted in a longer dimension of time that willed backwards as well as forwards, precisely the paradox expressed in Roger Griffin's concept of 'rooted modernism'. In the end, it was the more all-encompassing, legible, and 'situated'22 modernism of Piacentini that expressed Fascism's universalist aspirations in the 1930s far better than

20 Aristotle Kallis, "The "Fascist Effect": On the Dynamics of Political Hybridization in InterWar Europe' in Rethinking Fascism and Dictatorship, ed. Antonio Costa Pinto and Aristotle Kallis (Basingstoke: Palgrave, 2014), 13-41.

21 Louis Kahn, 'Monumentality' (1942) in Louis Kahn: Essential Texts, ed. Robert C. Twombly (New York and London: W.W. Norton, 2003), 21-31.

22 On the concept of a 'situated' modernist architecture, see Sarah Goldhagen, 'Coda: Reconceptualizing the Modern,' in Anxious Modernisms: Experimentation in Postwar Architectural Culture, ed. Sarah Goldhagen and Réjean Legault (Cambridge mA: MIT Press, 2000), 301-324; Hilde Heynen, 'Engaging Modernism,' Papers from the conference 'Team 10 between Modernity and the Everyday' (Delft, June 5-6, 2003), teamıoonline.org, accessed April 3, 2018, http://www.teamioonline.org/research/papers/delft2/heynen.pdf. 
the trenchant, polemical, intransigent, and heavily abstracted idiom of the rationalists.

\section{Fascism as Radical 'Third Way'}

In an insightful piece on Italian Fascism and its intellectual appeal as a third way' doctrine, Ruth Ben Ghiat argued that it was precisely the slippery nature of Fascist ideology, with its numerous contradictions, and the Fascist state's preference for mediation over polarization, that established Mussolini's regime as 'forward-looking regime of possibility with a doctrine in constant evolution. ${ }^{23}$ Faced with a host of culture wars raging inside the ranks of the Fascist regime and party, Mussolini generally avoided taking sides, opting instead for what has been described as the strange hybrid of Fascist 'totalitarian pluralism'. ${ }^{24}$ Fascism's 'protean nature'25 had often been misread in the past as ideological nihilism or mere propagandistic flair devoid of any political or cultural content. ${ }^{26}$ A growing number of scholars, however, have come to the conclusion that Fascist 'pluralism' and ideological pragmatism were deliberate, heavily orchestrated strategies of unifying through profusion and hybridity instead of dictating from above monolithic cultural choices or possessing no sense of culture at all. ${ }^{27}$

In this sense, the Fascist regime's encouragement of aesthetic pluralism in the 1920 s and early 1930 s was a primary expression of its deliberate intention to simulate an ideological third way in-the-making. The 1932 Doctrine of Fascism, the closest that Mussolini and his regime came to a sacred ideological canon, began with these words:

23 Ruth Ben-Ghiat, 'Italian Fascism and the Aesthetics of the Third Way', Journal of Contemporary History 31, no. 2 (1996): 311; emphasis added.

24 Marla Stone, The Patron State: Culture \& Politics in Fascist Italy (Princeton NJ: Princeton University Press, 1998), esp. 61-94.

25 Griffin, The Nature of Fascism, 333.

26 See the discussion in Roger Griffin, 'Notes towards the definition of fascist culture: The prospects for synergy between Marxist and liberal heuristics,' Renaissance and Modern Studies 42 (1999): 95-97.

27 See, for example, George L. Mosse's own trajectory from the idea that fascism was a peculiar form of nihilism to the understanding that it possessed distinct ideological and cultural content, in Karel Plessini, The Perils of Normalcy: George L. Mosse and the Remaking of Cultural History (Madison wi: University of Wisconsin Press, 2014), 52-55. 
Like all sound political conceptions, Fascism is action and it is thought; action in which doctrine is immanent, and doctrine arising from a given system of historical forces in which it is inserted, and working on them from within. It has therefore a form correlated to contingencies of time and space; but it has also an ideal content which makes it an expression of truth in the higher region of the history of thought. There is no way of exercising a spiritual influence in the world as a human will dominating the will of others, unless one has a conception both of the transient and the specific reality on which that action is to be exercized, and of the permanent and universal reality in which the transient dwells and has its being. ${ }^{28}$

The tension between ideology as a fixed doctrine and ideology as the organic, dynamic, prismatic, ever-shifting, reflexive, and open-ended product of historical forces lay at the heart of the Fascist dualism of action and thought. Jeffrey Schnapp has highlighted its nature as an 'unstable mix of dreams of radical restoration and rupture. ${ }^{29}$ Fascism's revolutionary spirit was predicated on this very notion of rupture with a past that nevertheless excavated and preserved its elemental quality, its irreducible historical essence and universal validity, in the end its sense of a radical continuity, radical in its etymological meaning of 'rooted'. Fascism's relationship with the past was thus more complex than either continuity or break can signify. In fact, the very essence of the fascist rupture was a necessary yet conditional strategy for rejoining 'historic time' and realising the full potential of history, so that 'history itself can start again and fulfil its meaning. ${ }^{30}$ In this sense, Fascism sought to be both time-less and time- and space-bound, universal and situated:

From beneath the ruins of liberal, socialist, and democratic doctrines, Fascism extracts those elements which are still vital. It preserves what may be described as 'the acquired fact' of history; it rejects everything

28 Benito Mussolini and Giovanni Gentile, 'Doctrine of Fascism,' in A Primer of Italian Fascism, ed. Jeffrey T. Schnapp, Olivia E. Sears and Maria G Stampino (Lincoln NE: University of Nebraska Press, 200o), 46-71. Emphasis added.

29 Jeffrey Schnapp, 'Flash Memories (Sironi on Exhibit),' in Donatello Among the Blackshirts: History and Modernity in the Visual Culture of Fascist Italy, ed. Claudia Lazzarro and Roger Crum (Ithaca NY: Cornell University Press, 2005), 224.

30 Claudio Fogu, The Historic Imaginary: Politics of History in Fascist Italy (Toronto: University of Toronto Press, 2003); and 'To make history present,' in Donatello Among the Blackshirts: History and Modernity in the Visual Culture of Fascist Italy, ed. Claudia Lazzarro and Roger Crum (Ithaca NY: Cornell University Press, 2005), 33-52. 
else. That is to say, it rejects the idea of a doctrine suited to all times and to all people.... It is logical for a new doctrine to make use of the vital elements of other doctrines. No doctrine was ever born quite new and bright and unheard of. No doctrine can claim absolute originality. It is always connected, if only historically, with those that preceded it and those that will follow it. ${ }^{31}$

Fascism appeared to pursue an impossible dream of an equilibrium between binary opposites - revolutionary yet rooted, universal yet 'situated' in its spatial and temporal habitus. ${ }^{32}$ But this is the hallmark of every genuine third-way ideology: the dream of forging new possibilities for the future through mining seemingly polar and incompatible intentions. ${ }^{33} \mathrm{~A}$ new equilibrium had to be sought both extrinsically and intrinsically. On the one hand, fascism was a novel universal political paradigm eclipsing, but also selectively drawing from, liberalism, capitalism, and socialism. On the other hand, Fascism was a movement hosting a volatile synthesis of diverse, often diametrically opposed ideological strands fighting for the soul of the movement and the future direction of the regime. True to its ambition to forge a third way, Mussolini's Fascism functioned as a broad and fairly accepting canopy, operating like a 'voracious amoeba $^{\prime 34}$ and thus transforming the absence of a fixed, exclusive doctrine into its primary virtue.

For a long time, this was Fascism in power but still very much ex ante, with numerous and wildly diverse futures in contention. A 'regime of possibility' with such an unstable, fluid ideological core required negotiations in every sphere of discourse and policy. For David Roberts, it remained an 'unstable and volatile mix, even as the regime embarked on a novel, self-proclaimed totalitarian direction'. ${ }^{35}$ Pluralism was fed by the discrete intellectual prehistories of the diverse constituencies that subscribed to the Fascist totalitarian project. The dust did start to settle in the second half of the 1920s. The introduction of the corporatist Labour Charter (Carta del Lavoro) in 1927 marked the

31 Mussolini and Gentile, 'Doctrine of Fascism'.

32 Roger Griffin, 'Fascism's Modernist Revolution: A New Paradigm for the Study of Rightwing Dictatorships,' Fascism 5 (2016): 126-128, DOI: 10.1163/22116257-00502002; Roger Griffin, Modernism and Fascism: The Sense of a Beginning under Mussolini and Hitler (Basingstoke: Palgrave, 2007), 233-234.

33 Bastow and Martin, Third Way Discourse, 150-153.

34 Richard Etlin, Modernism in Italian Architecture, 1890-1940 (Cambridge MA: MIT Press, 1991), 387-389.

35 David Roberts, The Totalitarian Experiment in Twentieth-century Europe: Understanding the Poverty of Great Politics (New York: Routledge, 2006), 279. 
beginning of a radical transformation of the regime's economic and political physiognomy. ${ }^{36}$ Soon afterwards, Mussolini also appeared to have made his mind up in favour of ruralism and against urbanization. In an article published in Popolo d'Italia on 22 November 1928 under the title Sfollare la città [Empty out the cities], he stated that he considered the mounting inward migration to the cities as a sign of continuing 'decadence' that had to be eradicated. The goal, the Duce stated, was an overall increase of Italy's population by twenty million by $195^{\circ}$ to at least sixty million by $195^{\circ}$, directed at the countryside, in conjunction with a systematic policy to increase agricultural production and overall economic productivity. ${ }^{37}$ But the debates did not abate. Members of the strapaese [hyper-village] group, who shared an intense disdain for the onslaught of western modernity, organized around the cultural review Il Selvaggio, which launched a full-on attack on modern urban life as part of their counter-vision of a return to a more rural, more traditional, more 'Italian' way of life. Il Selvaggio attacked with equal hostility the Futurists (whom it accused of having embraced the aesthetic 'barbarism' and hegemonic cultural media of 'western' modernity) and the views of the so-called Novecento group. The Novecento was a loose cultural grouping seeking to provide a corrective to both the perceived growing influence of the Fascist intransigents in the mid1920 and the performative excesses of the avant-gardes exemplified by Futurism. Instead, they proposed a balanced, sensitive mediation between national cultural tradition and international aesthetic inspiration. On their part, the $\mathrm{Fu}$ turists responded with trademark polemical excess by rejecting both the strapaese and Novecento competing visions in favour of his own vision of stracielo [hyper-sky] - a violent celebration of speed and technology with a futural and anti-historical/-traditional thrust. ${ }^{38}$

These and other polemics about Fascism's future direction of ideological and political travel kept raging in the ranks of the regime throughout the second half of the 1920s. What is indeed striking is how the field of architecture subsumed them all and transformed them into competing programmes that extended from the design of individual buildings to the planning and organization of space as a whole to the radical utopian re-imagining of communal

36 Matteo Pasetti, 'The Fascist Labour Charter and its transnational spread,' in Corporatism and Fascism: The Corporatist Wave in Europe, ed. António Costa Pinto (London and New York: Routledge, 2017), 60-77.

37 J.M. Musacchio, 'Mussolini, Mothers, and Maiolicain,' in Donatello Among the Blackshirts: History and Modernity in the Visual Culture of Fascist Italy, ed. Claudia Lazzarro and Roger Crum (Ithaca NY: Cornell University Press, 2005), 145-156.

38 C. Salaris, Marinetti: Arte e vita futurista (Rome: Editori Riuniti, 1997), 263-265. 
life. ${ }^{39}$ For the rich and fascinatingly acrimonious debates on architecture in interwar Italy ${ }^{40}$ were about much more than style and the quest for aesthetic primacy. While matters of material construction, composition and design, social and political function of building, and spatial planning provided the impetus and focus for such debates, they also referenced profoundly symbolic visions of social, political, cultural, and anthropological transformation. Architecture became the discursive terrain that turned a host of individual polemics about modernity and tradition, city and ruralism, nationalism and openness to international influences, as well as the role of the state as arbiter of political, socio-economic, and cultural life - into programmatic 'total' futures.

\section{Razionalismo: The promise of an Architectural 'Third Way'}

When a group of young architects established the Movimento Italiano per l'Architettura Razionale [MIAR; Italian Movement for Modern Architecture] in 1928 , they were responding to the deepening of the rift between modernity and tradition at the heart of the Fascist regime. MIAR mobilized across the country to make the case for modernist - functional, pure, abstracted, rational - architecture in the face of a concerted opposition from conservative cultural critics, political reactionaries, and the academic architectural establishment who rejected this brand of modernism as alien and detrimental to the Italian context. MIAR gave voice and gravitas to a cultural rebellion, the intellectual foundations of which had been laid down in Milan less than two years earlier. In late 1926, seven graduates of the Milan Polytechnic in their mid-twenties published four articles that amounted to a manifesto announcing a new wave of modernism in Italy. The authors - Ubaldo Castagnoli, Luigi Figini, Guido Frette, Sebastiano Larco, Gino Pollini, Giuseppe Terragni, and Carlo Enrico Rava, now collectively known as Gruppo 7 - produced their texts in a very different political and cultural environment after the declaration of the Fascist dictatorship in January 1925. Aware of the peripheral position of Italy in the modern architectural and aesthetic debates but eager to register their new voice in a milieu of effervescent anticipation, the Gruppo 7 endeavoured to produce the first articulate synthesis of diverse modernist currents in (Fascist) Italy. ${ }^{41}$

39 Nil Santianez, Topographies of Fascism: Habitus, Space, and Writing in Twentieth-century Spain (Toronto: University of Toronto Press, 2013), 6.

40 Terry Kirk, The Architecture of Modern Italy. Vol 2: Visions of Utopia, 19oo-Present (New York: Princeton Architectural Press, 2005), 69-144.

41 Etlin, Modernism in Italian Architecture, 224-254. 
In many ways, the Gruppo 7 members were attempting a supremely delicate balancing act, charting their own, modern version of a 'third way' for a nascent 'Fascist' architecture. They expressed their aversion to the conservative spirit of accademismo with its historicist obsessions. At the same time, however, they were highly critical of the Futurist violent rejection of tradition or disdain of fundamental, diachronic norms. Their goal, as they stressed, was to inspire this 'new spirit', to 'bring it to its most extreme consequences, until it dictates to the other nations a new style, just like in the great periods of (Italian) past'. Only through the embrace of these new values, they argued, could Italian architecture 'arrive at a new classic monumentality ... derived precisely from rationalism (razionalismo)'. For the Gruppo 7 , the main challenge was to anchor this 'new spirit' within a sensitive, but not unqualified, dialogue with the past, in effect to discover an alternative rooted modernism to that offered by variations of stripped classicism: 'the youth of today follow a wholly different route: we all felt the great necessity for clarity, for revision, for order ... Our prerogative ... is a desire for lucidity and reason.... Between our past and our present there is no incompatibility. We do not wish to break with tradition; it is tradition that transforms itself, that assumes new forms and aspects, through which only few recognize it. ${ }^{\prime 2}$

In 1928, MIAR took up the battle launched by the Gruppo 7 and decided to go for broke by organising its first national exhibition of rationalist architecture in Rome. The event offered an opportunity to showcase buildings and designs from a new group of architects determined to popularize the canon of modernist architecture in a country that still appeared resistant to its overarching principles, aesthetic values, and constructive sensibilities. The exhibition did succeed on numerous fronts. It helped transform a range of dissident discourses on the future of architecture into a formal statement of collective, ambitious architectural programme underpinned by the diversity of designs showcased at the exhibition. It also placed an essentially northern countercultural initiative on the national map, attracting the keen (though not always supportive) interest of experts from across the country. At a critical moment in the formation of a new cultural consciousness under the Fascist regime, when a sense of pluralism and open-ended opportunity for influencing or even shaping a Fascist cultural field was increasingly evident to the various stakeholders,

42 The four Gruppo 7 articles from which the quotes are taken: 'Architettura I,' Rassegna Italiana 18, no. 103 (1926): 849-854; 'Architettura II: Gli Stranieri,' Rassegna Italiana 19, no. 105 (1927): 129-137; 'Architettura III: Impreparazione, Incompresione, Pregiudizi,' Rassegna Italiana 19, no. 106 (1927): 247-252; 'Architettura IV: Una Nuova Epoca Arcaica,' Rassegna Italiana 19, no.108 (1927): 467-472. 
MIAR's first exhibition launched a bold claim to architectural hegemony and took it to the far less welcoming environment of Rome. ${ }^{43}$

The success of the first MIAR exhibition paved the way for a second, far more ambitious and controversial one in 1931. Pier Maria Bardi, the formidable publicist nous of the movement, now petitioned Mussolini with the proposition to sanction rationalist architecture as the official art of the (Fascist) state. ${ }^{44}$ The venue for the second exhibition this time was the Galleria di Roma, curated by Bardi himself. It was within the few months during and immediately after the exhibition that the rationalist movement went from near-triumph to a public relations disaster from which it never truly recovered. Bardi and the leading figures of the rationalist movement conceived of the second exhibition as an opportunity to launch a daring bid for cultural hegemony under the auspices of the Fascist regime. 'To build, for Fascism, means to remain', he proclaimed, adding that this task would fall on the shoulders of the (rationalist) architects. ${ }^{45}$ In a barrage of publications, both Bardi and Terragni sketched a future for rationalist architecture as an official arte di stato [art of the state]. In his contribution to the debate, Terragni envisioned a new relationship between architecture, state, and the public sentiment that was not strictly identified with the state but nevertheless fulfilled a moral and political role of the first order. ${ }^{46}$ Bardi went one crucial step further. Arguing that only architecture had the power to realize and express the will of the state for 'total' ordering of space and life under its aegis, he called on Mussolini to sanction rationalist architecture as the sole expression of Fascism capable of rendering the triumph of the Fascist ideal eternal and visible to the rest of the world. ${ }^{47}$

Such a daring bid was justified through the conviction that the 'new' architecture was uniquely capable of crystallising and then materializing the will of the Fascist state through the design of the built environment and in a form

43 See the various contemporary contributions about this landmark event collected in Michele Cennamo, ed., Materialiper l'Analisi dell'Architettura Moderna: La prima Esposizione Italiana di Architettura Razionale (Naples: Fiorentino 1973).

44 Francesco Tentori Pietro Maria Bardi: Primo attore del razionalismo (Turin: Testo \& Immagine, 2002), 45-50; Pietro Maria Bardi con le cronache artistiche de 'L'Ambrosiano' 19301933 (Milan: Mazzotta, 1990), 17-65.

45 Pier Maria Bardi, Rapporto sull'architettura (per Mussolini) (Rome: Edizioni di ‘Critica Fascista', 1931), 9.

46 The original articles: Pier Maria Bardi, 'Architettura, Arte di Stato,' and Giuseppe Terragni, 'Architettura di Stato?' both in L'Ambrosiano, 31 January 1931 and 11 February 1931 respectively.

47 Hanno-Walter Kruft, History of Architectural Theory (New York: Princeton Architectural Press, 1994), 411-412. 
that would 'remain'. The primary discursive problem facing the rationalists, however, was to present their version of a Fascist future as rooted in a cogent mediation between tradition and modernity, that is between the present-past of Italian Fascism and the present-future of a universal 'fascist century'. The Gruppo 7 in 1926-27 had already anticipated this tension by suggesting two paths of synthesis: a recovery of the ineliminable, ageless core of tradition, freed from the fetishism of 'fixed ideas' about the past; and a return to the purity and dignity of simple forms, associated with the classical spirit. It was this word - 'classic' (classico) - that invited the most disparate and often contrasting interpretations in subsequent years. Though etymologically related, derivatives such as classicità and classicismo possessed significantly divergent meanings for the participants to the architectural debates of the $1930{ }^{48}{ }^{4}$ For the rationalists, classicità was the expression of this timeless, authentic classic spirit - a spirit rooted in the most celebrated traditions of ancient GraecoRoman architecture but then transformed and re-interpreted through different visual forms and materials throughout the centuries and rendered once again universal in the architecture of the international 'modern movement'. In contrast to the radical rupture between past and future that the Futurists had posited ${ }^{49}$ the MIAR rationalists sought to present their total architectural vision as the product of a genuine synthesis of modernity and tradition, universality and Italian singularity. ${ }^{50}$ As Bardi boldly claimed in his direct appeal to Mussolini in 1931, 'the (young) rationalist architects of our generation are the traditionalists'. And it was only this rationalism that was capable of not just passively expressing, but also of shaping discursively, setting in stone, and making eternal the spirit of Fascism.

The bid was ambitious, provocative, and in the end ill-judged. Ever the shrewd impresario, Bardi used the occasion the exhibit his Tavola degli Orrori, a polemical collage that ridiculed some of the most established and respected names in the Italian architectural profession. Bardi had originally intended to use a large room of his gallery to name and shame what he considered as some of the most grotesque examples of 'academic' and 'pseudo-modern'

48 Luigi Cavallo 'Classicità, classicismo: Una traccia fra pittori, critici, riviste,' in L'idea del classico: Temi classici nell'arte italiana degli anni Venti, ed. E. Pontiggia and M. Quesada (Milan: Fabbri, 1992), 63-109; Bruno Zevi, Sterzate architettoniche: Conflitti e polemiche degli anni settanta-novanta (Bari: Laterza, 1992), 98-102.

49 Günter Berghaus Futurism and Politics: Between Anarchist Rebellion and Fascist Reaction, 1909-1944 (Oxford: Berghahn, 1996), 92-171.

5o Sergio Poretti Modernismi italian: Architettura e costruzione nel Novecento (Rome: Gangemi, 2008), 64-81; Patetta, L'Architettura in Italia, 34-35. 
architecture; but he eventually opted for the collage idea as it achieved the same publicity effect while also maximising exhibition space for rationalist works and designs. ${ }^{51}$ The Tavola sacrificed subtlety for maximum public impact. Works by important figures of the profession such as Gustavo Giovannoni, Marcello Piacentini, and Armando Brasini were clearly identifiable on the composition. In addition, Bardi accompanied the Tavola with a sardonic text that disparaged the figure of the bourgeois 'culturalist architect': 'we killed the culturalist architect, we opened the skull, and we have carefully extracted all his paradise. We reassembled and meticulously photographed it in order to give an accurate picture to our readers. Here, at last, what it is. ${ }^{52}$

Although Mussolini accepted Bardi's invitation and attended the inauguration of the 1931 exhibition, the Duce's official endorsement of rationalist architecture so passionately pursued by Bardi never came. Instead, soon after the triumphant opening, the exhibition descended into a public relations disaster for MIAR and its members. Antagonising the usual suspects - proponents of historicism like the art critic Ugo Ojetti; traditionalists like the strapaesini Maccari and Soffici; or even intransigents, such as the former PNF secretary Roberto Farinacci - was one thing; but picking a fight with Piacentini proved in hindsight to be a step too far. Although in 1931 Piacentini had yet to rise to the status of a de facto official architect of Mussolini's regime, he was a highly regarded practitioner with a widely appreciated gift for synthesis and measure. In 1930-31 he had entered into a series of exchanges with the head of MIAR, Adalberto Libera, and the editor of the modernist architectural journal Casabella, Giuseppe Pagano, about the relevance of the rationalists' aesthetic values to the Italian cultural and natural milieu. ${ }^{53}$ For Piacentini, the kind of modernism that MIAR espoused was too profoundly indebted to the sensibilities of 'northern' Europe and did not match the environmental and historical characteristics of Italy.54 Still, his attempts at synthesis, both of architectural styles and on the level of professional partnerships, had also exposed him to the critique of Fascist conservative and intransigent circles without winning him any lasting favours with the rationalist camp. Piacentini may have represented an earlier generation with a more conservative, 'culturalist' approach to

\footnotetext{
51 Tantori, Pietro Maria Bardi, 44-45.

52 Pier Maria Bardi, 'La Tavola degli orrori alla Mostra d'Architettura Razionale,' L'Ambrosiano, 31 March 1931; reproduced in Quadrante 2 (1933): 10.

53 Among them, Marcello Piacentini, 'Dove è irragionevole l'architettura razionale,' Dedalo (1931): 275. See in general Fabrizio Brunetti, Architetti e Fascismo (Florence: Alinea, 1993), 173; Patetta, L'Architettura in Italia, 275-313.

54 Kruft, History of Architectural Theory, 410-411.
} 
modern architecture and a less radical or audacious creative edge when compared to MIAR's young rationalists; but he was far from the sworn opponent of modernist architecture that the MIAR rationalists portrayed him as. ${ }^{55}$

\section{'The man of two hundred style': The 'Third Way' of Marcello Piacentini}

Piacentini, 'the man of one hundred opinions, of two hundred styles, of three hundred manners ... a monster with seven heads' as the cultural critic Carlo Belli referred to him disparagingly in a 1931 letter to Bardi, ${ }^{56}$ had already given ample evidence of his ability to unify opposing trends and synthesize seemingly incompatible programmatic positions in architecture. In 1927 Piacentini participated in the competition for the new Ministry of the Corporations on Via Veneto in Rome. The significance of this competition - architectural and political - cannot be exaggerated. In 1927 corporatism was just starting its exhilarating upward political trajectory. As the epitome of a putatively viable and authentic 'third way' total paradigm encompassing politics and economy, state and society, Fascist corporatism needed its symbolic civic temple at the heart of the Fascist state. Until that point, the official architectural style for public buildings had not changed significantly in comparison to that of the preceding Liberal period. Two new ministry edifices, of Education in Trastevere and of Communications in Via Nomentana, were completed by 1930, both in the trademark eclectic neo-classical style that had been in vogue since the late nineteenth century. Given, however, the centrality of corporatism in the official Fascist discourse of the late 1920s, the competition for the ministry's seat was invested with a symbolic significance that far exceeded any other public project up to that point. In fact, it was widely believed that this competition was as much about the building itself as about ideas for a Fascist official architectural 'style' to be used in all future public - government and party - buildings. ${ }^{57}$

The 1926-27 competition for the new seat of the Ministry of Corporations by invitation only - produced a winning design authored by a team of Roman architects (headed by Pietro Aschieri, with Mario De Renzi and Giuseppe Wittinch among the members of the team). The project - a partly hollow curved

55 David Rifkind, Quadrante and the Politicization of Architectural Discourse in Fascist Italy (PhD diss., Columbia University, 2007), 224-236.

56 Quoted in Rifkind, Quadrante, 235.

57 Giorgio Pigafetta, Ilaria Abbondandolo, Marco Trisciuoglio, Architettura tradizionalista: architetti, opere, teorie (Milan: Jaca, 2002), 241. 
volume with a superimposed C-shaped skyscraper - was praised for its daring interpretation of the available space (a difficult, curved on one side and ascending plot near the foot of Via Veneto).${ }^{58}$ It was also singled out for its imaginative fusion of modern stylistic references with abstracted traditional features from Rome's vast architectural register. ${ }^{59}$ However, in the end the judging committee changed its mind and awarded the first prize for the competition to Giuseppe Vaccaro and Marcello Piacentini, who collaborated in the construction of the ministry building between 1929 and 1932. The PiacentiniVaccaro partnership produced an austere monumental construction of concrete and marble that was nevertheless highly untypical and original in terms of decoration and materials. ${ }^{60} \mathrm{~A}$ team of notable artists - among them the painter Mario Sironi - came together in a creative partnership under Piacentini's direction to execute an extensive decorative programme for the new ministry building. These decorations, and the highly innovative use of functional features and materials in its interior, transformed the building from a cold bureaucratic institution into a symbolic exaltation of Fascist social and economic policy, at a time that marked the peak of the Fascist corporatist parabola in the wake of the publication of the 1927 Labour Charter. ${ }^{61}$

When it was completed in 1932, the ministry building suggested an architectural dialogue between modernism and classically-inspired monumentalism, as well as between an international architectural language of abstraction and a classical sensibility grounded in the historical layers of Rome, a proposal once again true to the spirit of 'rooted modernism'. Inevitably, this was also the hybrid response to the debates on modernism-versus-tradition that was bound

58 Piero Spagnesi 'Roma 1921-43. I concorsi di architettura,' in L'Architettura dell'Altra Modernita: Atti del XXVI Congresso di Storia dell'Architettura, Roma 11-13 Aprile 2007, ed. M Docci and M.G. Turco (Rome: Gangemi, 2010), 359 .

59 Plinio Marconi, 'Due progetti per il palazzo delle Corporazioni in Roma,' Architettura e Arti Decorative 2, no. 9 (1928): 398-401; Dario Donetti, 'Pietro Aschieri nei concorsi di architettura dell'Italia fascista'. Paper presented at the conference 'Concursos de arquitectura: 14 Congreso Internacional de Expresión Gráfica Arquitectónica', Oporto, 31 May to 2 June 2012.

6o Giuseppe Pensabene, 'Il Palazzo delle Corporazioni' Edilizia Moderna, 12/13 (1934): 3-9; Franco Casetti, 'Il nuovo palazzo del Ministero delle Corporazion,' La Rivista Illustrata del Popolo d'Italia 10, no. 1 (1932): 38-45.

61 Franco Borsi, Gabriele Morolli, Daniela Fonti, Il Palazzo dell'Industria (Rome: Editalia, 1986), 155-169; and in general, Laura Malvano, Fascismo e Politica dell'Immagine (Turin: Bollati Boringhieri, 1988). On Sironi, see the seminal work of Emily Braun, Mario Sironi and Italian Modernism: Art and Politics under Fascism (Cambridge: Cambridge University Press. 2000). 


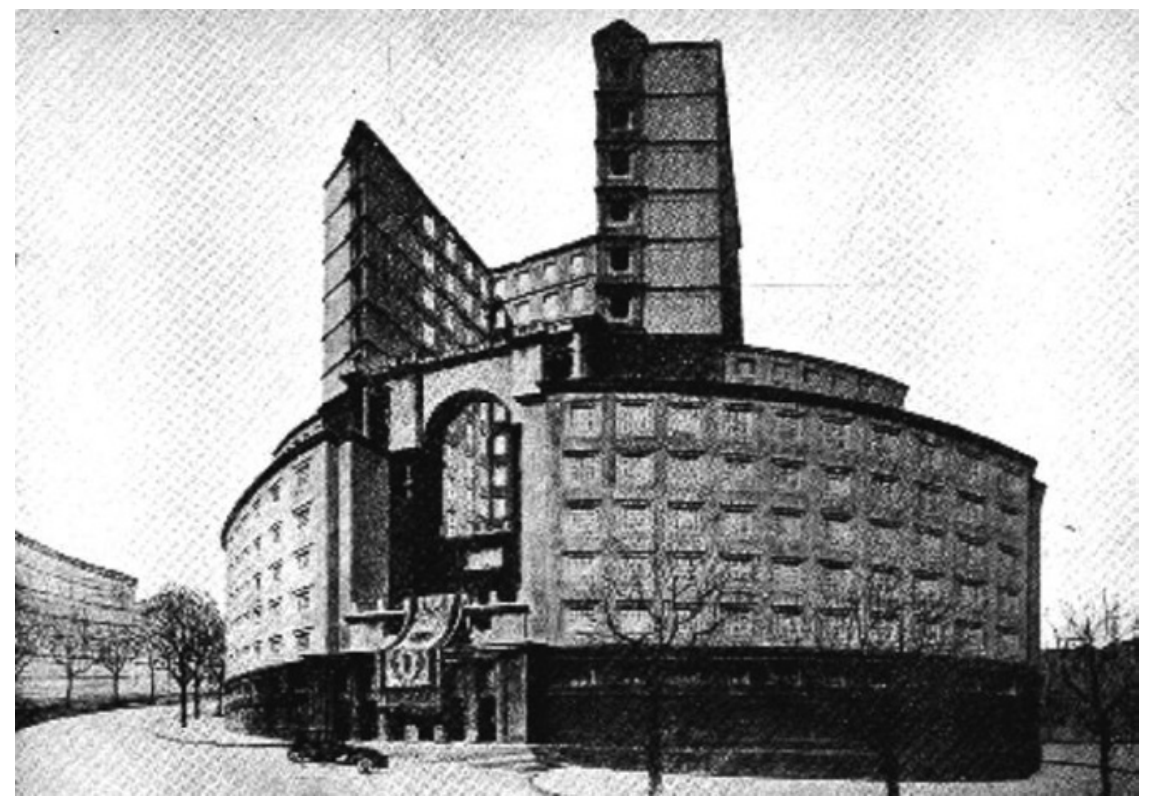

FIGURE 1 Competition entry of the Gruppo Aschieri for the Ministry of Corporations, 1926 (arch. Pietro Aschieri, Mario De Renzi, Luigi Ciarrocchi, Mario Marchi, Costantino Vetriani, Giovanni Wittinch)

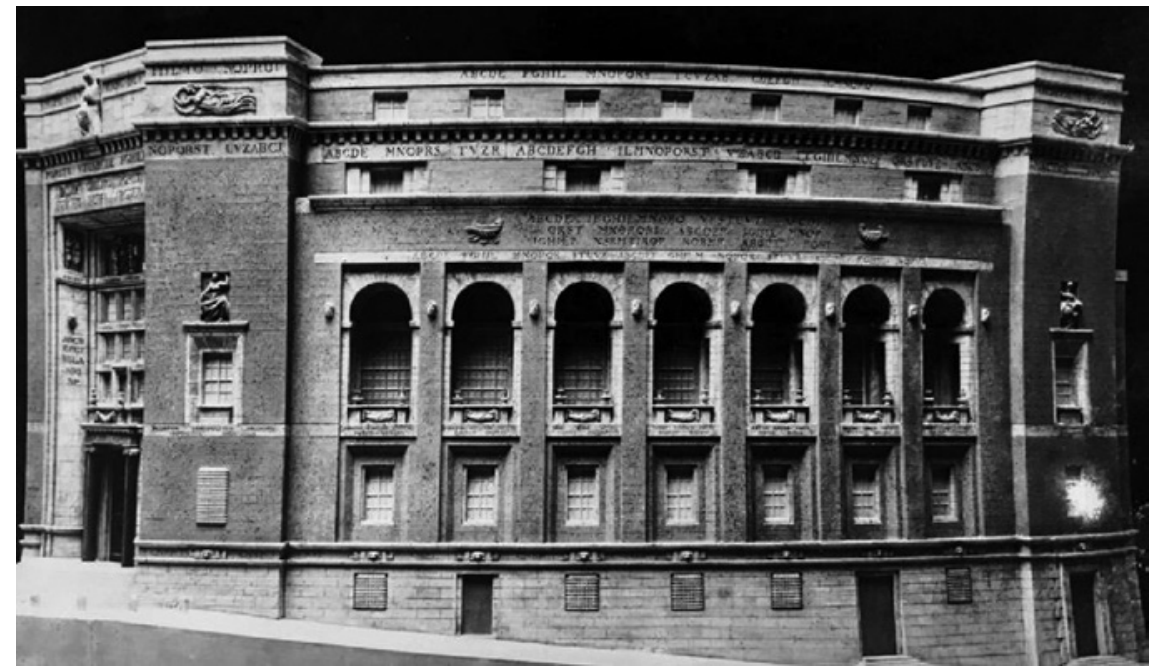

FIGURE 2 Ministry of Corporations, 1928-32 (arch. Marcello Piacentini and Giuseppe Vaccaro). With the kind permission of Fondo Marcello Piacentini, Università degli Studi di Firenze. Biblioteca di Scienze Tecnologiche 
to polarize the critical reception of the project. While many praised the virtues of synthesis, fusion, and respect for the heritage of the surrounding spaces, others - especially those sponsoring the need for a 'new' architecture - inveighed against what they saw as a gratuitous pastiche of false traditions steeped in a pseudo-monumentalism. ${ }^{62}$ Piacentini was yet again plunged in a two-front war: on the one hand, against vocal rationalists like Pagano who were accusing him of a new rhetorical monumentality that betrayed the values of purity, function, and timelessness that inhered in modern architecture; on the other hand, against traditionalists like the cultural critic Ugo Ojetti who continued to campaign for a more literal pursuit of 'situating' new architecture in its local/regional/national surroundings against rationalism's perceived universal foundations. ${ }^{63}$

As the debates on architecture continued to increase in intensity and bitterness in the first half of the 1930s, so Piacentini's role as both arbiter and unifier grew in importance and stature. As David Rifkind has demonstrated, it was that same Piacentini, so savagely mocked on the "Tavola" collage and through numerous articles penned by Bardi, who worked quietly but effectively to safeguard or even relaunch the careers of many young rationalists who had been tainted by association with MIAR. ${ }^{64}$ In fact, even more so than in the years between the first and the second MIAR exhibitions (1928-31), it was the 1932-35 period that marked the peak of the parabola of rationalism in Fascist Italy. This was the time of the Mostra della Rivoluzione Fascista [Exhibition of the Fascist Revolution], with its bold modernist facade by the Libera-Mario de Renzi partnership and the internal decorations by Giuseppe Terragni and Sironi; ${ }^{65}$ of the

62 Giuseppe Pagano, 'Del "monumentale" nell'architettura moderna,' Casabella 40 (1931): 9-14; Benedetto Coccia, Il Mondo Classico nell'Immaginario Contemporaneo (Rome: Apes, 2008), 150-151. Piacentini's stylistic pluralism proved controversial in relation to his other early major project in Rome, the Casa Madre dei Mutilati e Invalidi di Guerra, which divided contemporary critics between those who praised the building's austere monumentality and those who censured it as a mishap - for example, see the critical article of Giuseppe Pagano, 'Parliamo un po' di esposizioni,' Casabella 159-16o (1941): 2-4.

63 Laura Neri, 'Arches and Columns: The Debate between Piacentini and Ojetti, 1933,' Modulus, (1982): 7-17; Jobst Welge, 'Fascism Triumphans: On the architectural translation of Rome,' in Donatello Among the Blackshirts: History and Modernity in the Visual Culture of Fascist Italy, ed. Claudia Lazzarro and Roger Crum (Ithaca NY: Cornell University Press, 2005), 92-94.

64 Rifkind, Quadrante, 235; Thomas Schumacher, Surface \& symbol: Giuseppe Terragni and the architecture of Italian rationalism (New York: Princeton Architecture Press, 1991), 28-30.

65 Marla Stone, 'The Anatomy of a Propaganda Event: The Mostra della Rivoluzione Fascist,' Carte Italiane, 1, no. 12 (2009): 30-40; Jeffrey Schnapp, 'Mostre,' in Kunst und Propaganda 
5th Milan Triennale with its bold exhibition on modern housing and Gio Ponti's steel Torre Littorio in the midst of Parco Sempione; ${ }^{66}$ of the competition for the Florence railway station that produced a highly praised but also controversial winning project by Giovanni Michelucci; of Luigi Moretti's Accademia di Scherma (or Casa delle Armi) inside the Foro Mussolini (now Foro Italico) of Rome; 67 of Terragni's signature Casa del Fascio in his native Como (see below); and of the inauguration of the 'new town' of Sabaudia in the Pontine Marshes

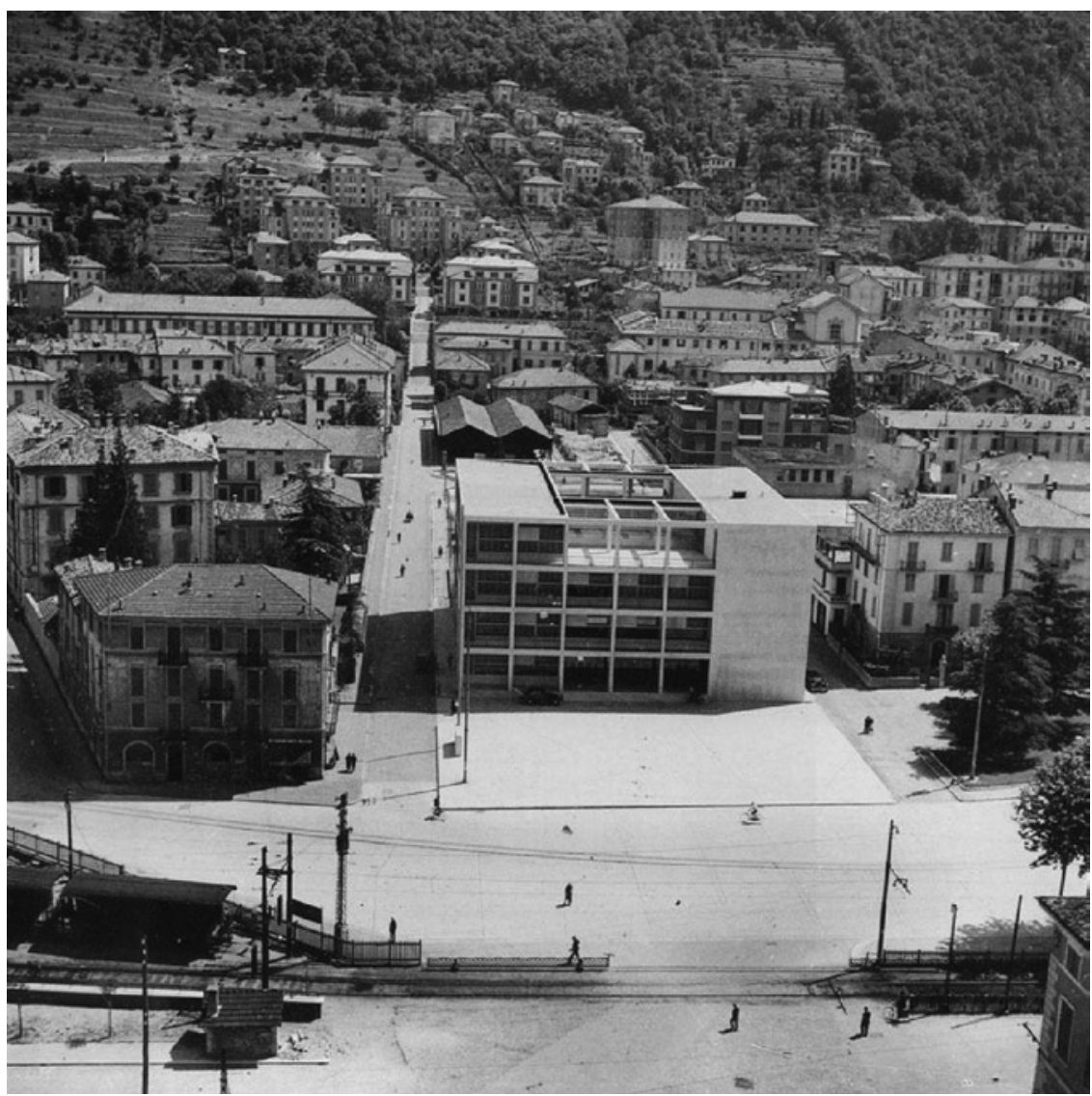

FIGURE 3 Casa del Fascio, Como, 1932-36 (arch. Giuseppe Terragni)

im Streit der Nationen 1930-1945, ed. H-J. Czech and N. Doll (Dresden: Sandstein, 2007), $78-85$.

66 Giovanni Denti, I monumenti nell'architettura moderna: Simbolo, memoria, luogo (Florence: AltraLinea, 2016), 6o-63.

67 Mario Ferrari, Luigi Moretti: Fencing Academy in the Mussolini's Forum, Rome 1933-1937 (Bari: Ilios, 2010). 


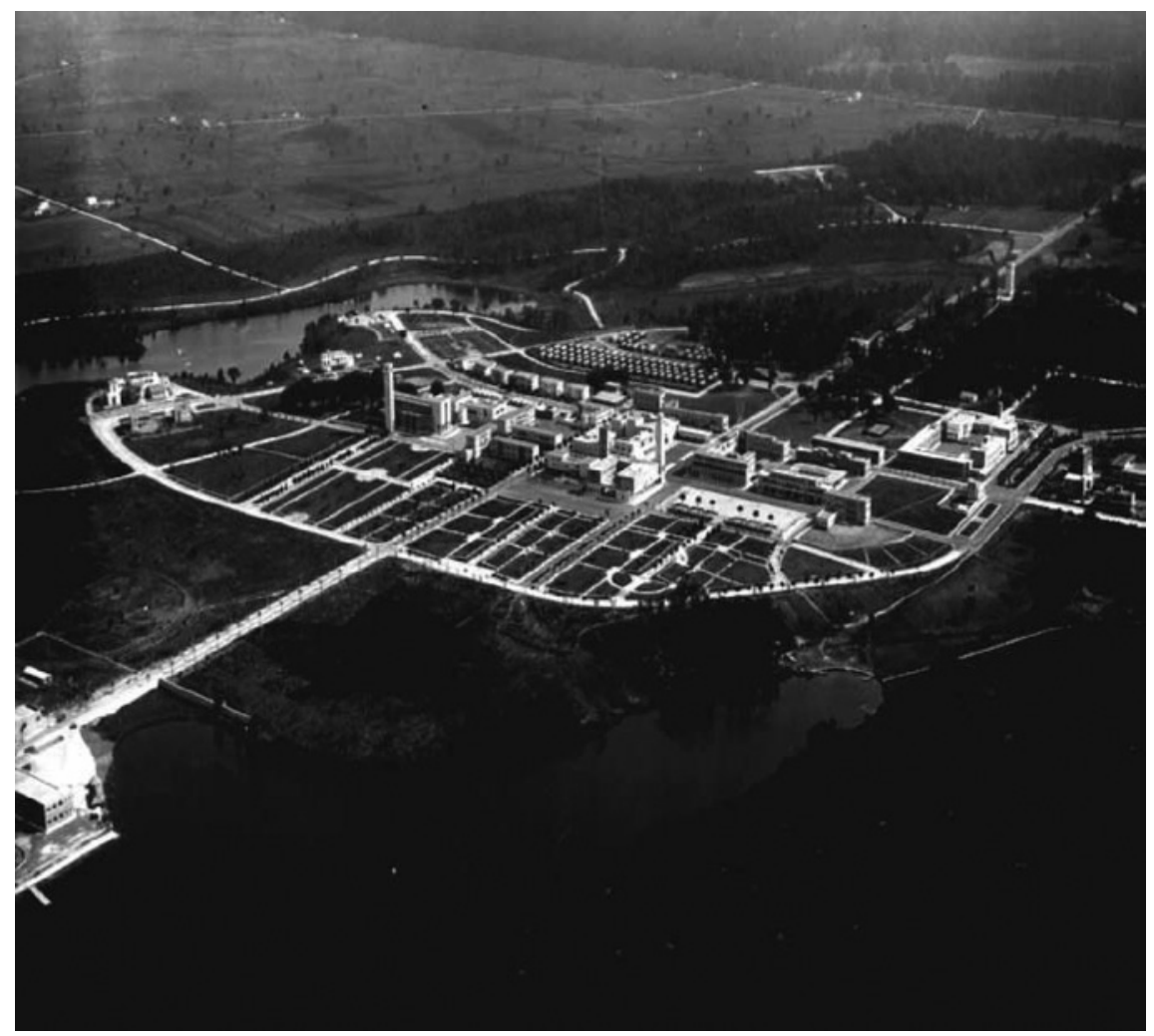

FIgURE 4 Aerial view of the 'new town' of Sabaudia, 1933-34 (arch. 'Gruppo Piccinato': Luigi Piccinato, Gino Cancellotti, Eugenio Montuori e Alfredo Scalpelli)

to the south of Rome, work of a different team of young modernist architects headed by Luigi Piccinato. 68

On his part, Piacentini assembled an extraordinary team of architects to work under his overall supervision on the first major civic project of the Fascist regime in Rome, the new university campus (Città Universitaria). His decision to turn the campus project into a kaleidoscopic collaborative project was of particular symbolic significance. It rehearsed a model for the execution of large-scale projects that would be used a few years later as the basis for the construction of the 1942 world fair quarter in the outskirts of Rome. More importantly, however, it established Piacentini's credentials as a powerful and supremely effective curator of 'aesthetic pluralism' in architecture and urban design. Piacentini used the opportunity offered by the landmark

68 For an overview see Aristotle Kallis, The Third Rome, 1922-1943: The Making of the Fascist Capital (Houndmills: Palgrave Mcmillan, 2014), 166-173. 


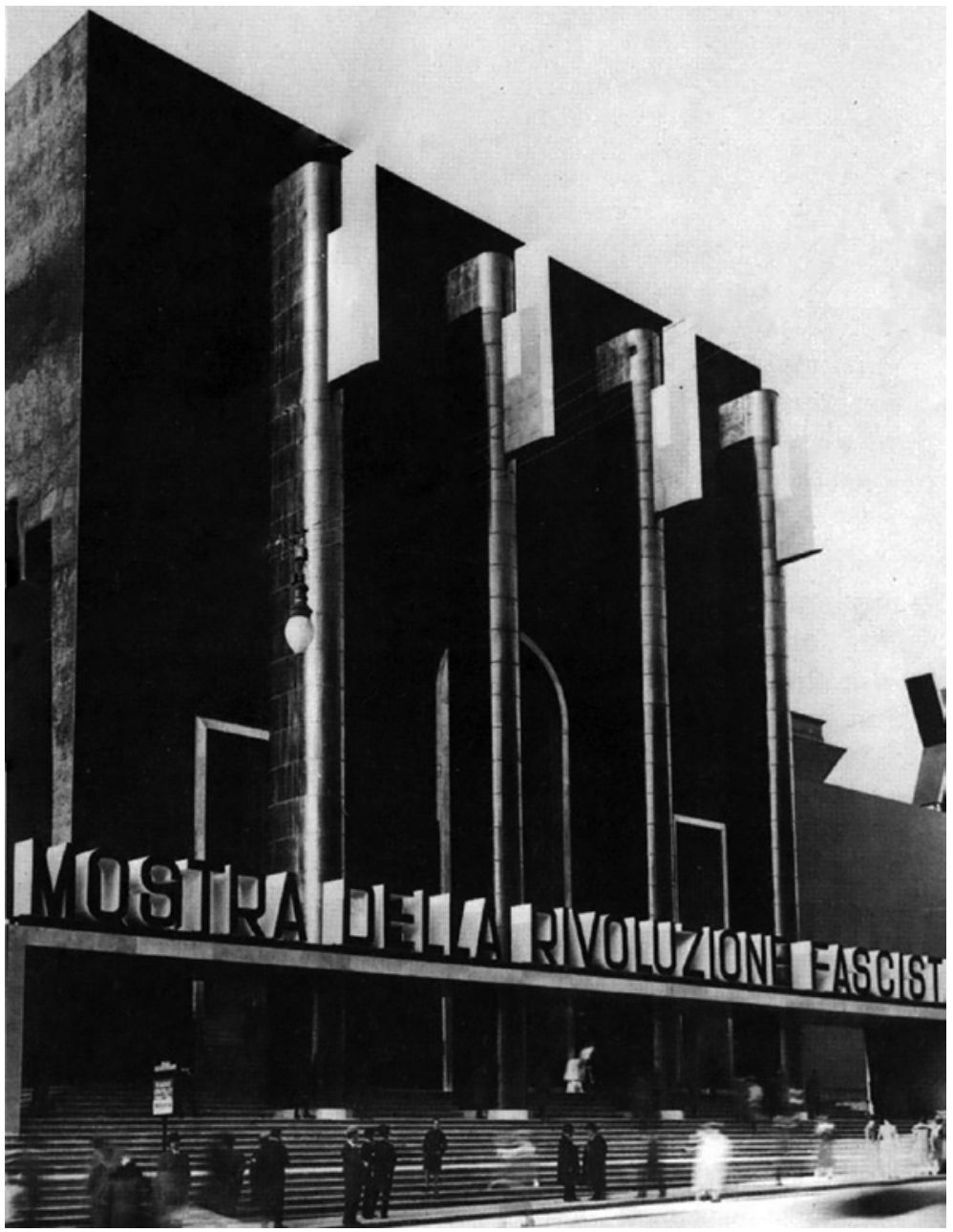

FIGURE 5 Façade of the Exhibition of the Fascist Revolution, 1932 (arch. Adalberto Libera and Mario de Renzi)

project to heal divisions and restore bridges with the rationalist constituency of architects while also rewarding some of his longest local collaborators. Surprisingly, the individual buildings that made up the campus divulged a sense of stylistic unity even in their aesthetic diversity. The result was a plural and refracted modernism, monumental yet abstracted, thoughtfully 'situated' in Rome's urban ambience and serving the regime's emerging discourse of a universal romanità ${ }^{69}$

69 Franco Purini, 'Geometrie della Sapienza,' in Marcello Piacentini Architetto, 1881-1960, ed. Giorgio Ciucci, Simonetta Lux and Franco Purini (Rome: Gangemi, 2010), 241-256; Sandro 


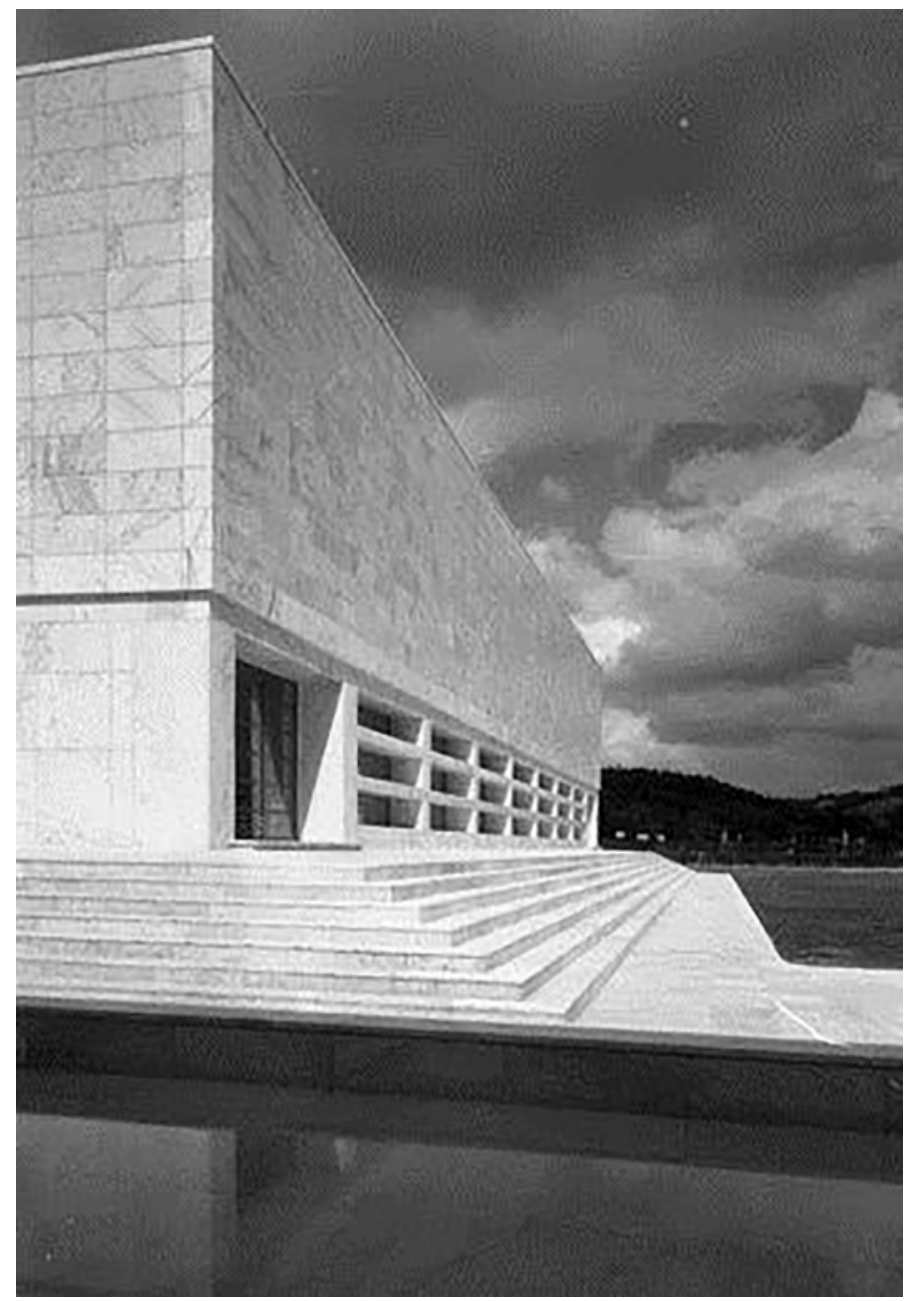

FIgURE 6 Accademia di Scherma, Foro Italico, Rome, 1934-36 (arch. Luigi Moretti)

The Città Universitaria represented the apex of the trademark broad-based synthesis - in style and professional consensus - pursued systematically by Piacentini since the late 1920s. In 1930 Piacentini had attempted to 'situate' a new, inclusive architectural-urbanistic opus that was both manifestly modern and distinctly autochthonous as an conscious, open-ended experiment with new materials, new forms, new constructive techniques, but filtered through

Benedetti, 'Marcello Piacentini: "il mio Moderno", in L'Architettura dell'altra' modernità: Atti del XXVI Congresso di Storia dell'Architettura, ed. Marina Docci, Maria Grazia Turco (Rome: Gangemi, 2011), 68. 


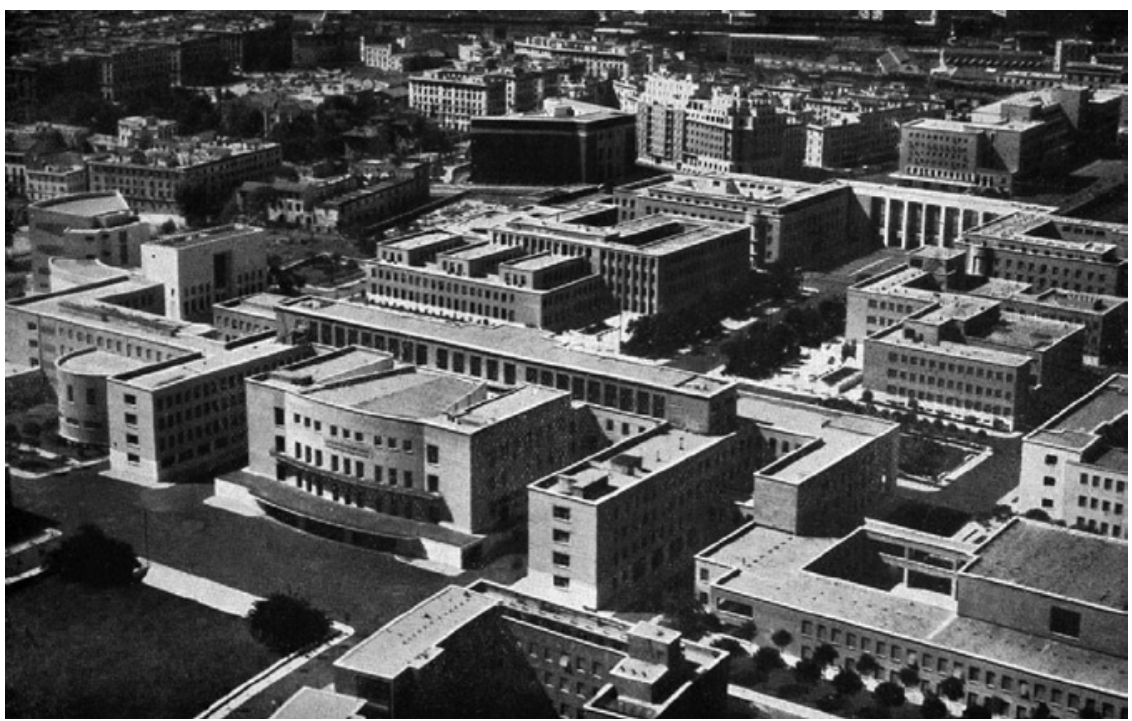

FIGURE 7 Citta Universitaria, 1932-35 (various architects under the supervision of Marcello Piacentini)

the cultural, artistic, and ambient qualities of its Italian context. ${ }^{70}$ His quest for a fluent synthesis over the emerging fault lines shone through his measured embrace of architectural rhythm but disdain of mechanical repetition, his declared passion 'for simplicity and sincerity of form without the complete repudiation of an opportune decorative element.' ${ }^{71}$

Here then was the most complete statement of Piacentini's vision for squaring the architectural circle - a monumental kind of modernism as the Fascist regime's official architecture, referencing both the contemporary and the traditional, the regional and the universal, without giving in either to provincialism or to a faceless internationalism of the machine aesthetics. While in terms of planning, the new university campus was a triumph of collaborative vision and work, its 'third way' stylistic tightrope walking was bound to alienate and enrage. Even before the project had been unveiled in 1935, Piacentini was accused by Ojetti of having betrayed the architectural legacies of both Rome and Italy by relying on so many modernist architects for such a signature civic project in the capital city. In a further twist of fate, Ojetti accused Piacentini of nothing less than 'deleterious avant-gardism.' ${ }^{72}$ In his response, Piacentini

$70 \quad$ Fulvio Irace, Giovanni Muzio: 1893-1982 (Milan: Electa, 1994), 27.

71 Marcello Piacentini, Architettura d'oggi (Rome: Cremonese, 1930), 62-63.

72 Ugo Ojetti, 'Lettera a Marcello Piacentini,' Pegaso 5, no. 2 (1933): 213-215. 
fiercely defended his choice of style and the broad base of his collaborators. Speaking as the authoritative spokesperson of a new official 'third way' architecture, he accused Ojetti of inventing false dichotomies between the 'classical' and the 'modern', the 'national' and the 'foreign.' ${ }^{73}$ Interestingly, Pagano came out in defence of Piacentini, in spite of their most profound programmatic differences. Above anything else, Pagano seemed to appreciate Piacentini's role in solidifying a broad front against modernism's reactionary critics at the very heart of the Fascist regime's official architecture. ${ }^{74}$ The two architects would continue their unlikely collaboration as the Fascist regime's semi-official architects with their pavilion for the 1937 Paris world fair: an abstract cubic frame made of reinforced concrete and a series of rhythmic glass surfaces but then injected with a series of abstracted classical elements (pillars, statues, galleries); while the interior was re-imagined as a receptacle for bold mini-pavilions executed by different architects that captured the essence of the collaborative broad-church approach that Piacentini had consistently championed. ${ }^{75}$

\section{Piacentini, the Architectural Impresario of the Fascist 'Third Way'}

Like Ojetti could not be placated by Piacentini's 'third way' stylistic mediations, Bardi would not accept that the battle for a rationalist architecture as 'art of the Fascist state' had been lost to Piacentini's brand of sub-modern compromise. In 1937, he published an article in which he accused Piacentini and Pagano's pavilion of plagiarising Terragni's landmark Casa del Fascio in Como. ${ }^{76}$ Bardi's accusation was a form of retaliation against Pagano, whom he suspected as the nous behind an anonymous article that had appeared in early January 1937, making a similar accusation of plagiarism against Terragni's Casa del Fascio but in his case referencing as sources examples of modern architecture from

73 Marcello Piacentini, 'Risposta a Ugo Ojetti,' Casabella 6, no. 2 (1933b): 3.

74 Fabrizio Brunetti, 'Pagano e Piacentini: dall' "intesa cordiale" alla "rottura", in Giuseppe Pagano: Architettura tra guerre e polemiche, ed. Fabrizio Brunetti (Florence: Alinea, 1991), $35^{-43 .}$

75 Flavia Marcello, 'Italians do it better: Fascist Italy's new brand of nationalism in the art and architecture of the Italian pavilion, Paris 1937,' in Architecture of great expositions 1937-1958: messages of peace, images of war, ed. Rika Devos, Alexander Ortenberg and Vladimir Paperny (London: Ashgate, 2015), 51-70. See also Agnoldomenico Pica, 'Il Padiglione italiano all' Esposizione internazionale di Parigi,' Rassegna di Architettura 7-8 (1937): 251-26o.

76 Pier Maria Bardi, 'Le fonti della fantasia,' Meridiano di Roma 20 December 1937, 31. 
northern Europe. ${ }^{77}$ Commissioned in 1932, Terragni's Casa del Fascio in Como was unveiled in 1936 and instantly caused controversy. ${ }^{78}$ Traditionalists derided the building as either soulless or unduly cosmopolitan and 'un-Italian.' ${ }^{79}$ But it was fellow travellers like Pagano, Persico, and Quadrante's co-founder Massimo Bontempelli who furnished the most surprising criticism of the building as inordinately 'monumental', stylistically pretentious, un-original, dishonest, and narcissistic. ${ }^{80}$ The local community refused to attend the inauguration ceremony, protesting against Terragni's arbitrary design choices that contravened earlier agreement and appeared as offensive to the setting of the building opposite the cathedral. Terragni rigorously defended his design choices in an article published in Quadrante. He explained that his design privileged the notion of an open 'house' for the local people and rejected the bureaucratic insipidness of an 'office'. He defended his controversial aesthetic choices by celebrating what he called the 'poetic qualities' of the building. Finally, he underlined how references to Italian tradition, classical legacies, Fascist political ideas, and Mussolini's programmatic declarations could be articulated through an architecture of subtle connotation and metaphor, avoiding bombastic historicism or literal references on the 'surface' of the building. ${ }^{81}$ For Terragni, pure form and spatial distribution were the unmistakable markers of a timeless Italian and 'Mediterranean' sensibility - rooted in the architecture of the ancient classical world but authentically reinvented and abstractly represented in the functionalist experiments of Italian interwar rationalism. ${ }^{82}$

Here then was the apex of the battle of competing 'third ways' that, however focused on architectural massing and style, referenced alternative visions for Fascism's future political universality. Terragni, like Bardi - who remained his most unswerving patron - and Alberto Sartoris - who also publicly defended Terragni against the accusations of plagiarism ${ }^{83}$-, thought of rationalism as a unique 'third way' experiment - universal and situated in a sense of Italian tradition and identity, autonomous and in dialogue with its surrounding

77 The anonymous article appeared on the journal La Sera, 6 January 1937; and Terragni's responses: 'Al direttore del giornale La Sera' and 'Confronti Utili: Chi plagia?' La Sera, 25 January 1937 and 16 March 1937 respectively.

78 Bruno Zevi, Giuseppe Terragni (Bologna: Zanichelli, 1980), 70-83; Poretti, Modernismi italiani, 64-81.

79 Ugo Ojetti, 'Supplica alla fantasi,' Corriere della Serra, 8 November 1937.

8o Rifkind, Quadrante, 314-317.

81 Giuseppe Terragni, 'La costruzione della Casa del Fascio di Como,' Quadrante 35, no. 6 (1936): 5-26.

82 Kallis, The Third Rome, 67-77.

83 Alberto Sartoris, 'Terragni plagia Terragni e i doveri dell'onestà,' L'Italia, 17 January 1937. 
context. For them, there was no contradiction in taking part in the proceedings of the CIAM IV conference in 1934, alongside functionalist architects and urban planners from northern European countries with well-known socialist beliefs, and serving Fascism with what they believed was an authentic and all-encompassing idiom for a new, rational and Italian, official Fascist architecture. Bardi engaged in a tenacious defence of Terragni's building with a special issue of Quadrante dedicated exclusively to the Casa del Fascio in Como. Fittingly, this issue - number $35^{-3} 6$ - was the last one that Quadrante ever published. A mildly critical of the building - opinion piece penned by the journal's co-editor Bontempelli was removed by Bardi before the issue went to press, causing a rift between the two editors that sealed the fate of both the journal and their creative partnership. ${ }^{84}$ Too polemical and uncompromising in tone, too intransigent in opinion, too inflexible towards alternative ideas, too tied to the strengths and flaws of particular personalities, Quadrante had aspired to re-launch the 1931 daring bid to anoint its particular brand of rationalist architecture to the status of the official 'art of the Fascist state' - and failed for all these reasons, this time irrevocably.

What Quadrante and its circle of talented architectural avant-gardists left behind was a glistening trail of the most delectable failures and near-misses among them, the two submissions by Terragni and the Milanese group for the Palazzo del Littorio competitions in 1934 and 1936, originally planned to appear opposite the Roman Forum and the Colosseum; the Danteum project, again destined for the Via dell'Impero at the heart of Rome; 85 the extraordinary ideas for the new regulatory plans of first Pavia and later Val d'Aosta, both conceived as realizations of the vision of corporatist urban planning, devised by the ввРR partnership (Banfi, Belgioioso, Peressutti, Rogers) and the engineer Gaetano Cioccia, with the enthusiastic sponsorship by Bardi and Bottai. ${ }^{86}$ But the unhappy outcome of the Pavia and Val d'Aosta projects, as well as the unsatisfactory conclusion of the Palazzo deal Littorio competitions (the winning project by Enrico Del Debbio, Arnaldo Foschini, and Vittorio Morpurgo appeared as a direct descendant of the Piacentinian 'third way' idiom of

\footnotetext{
84 Rifkind, Quadrante, 317-318.

85 Aristotle Kallis, “A Miglior Tempo...”: What Fascism did not build in Rome,' Journal of Modern Italian Studies 16, no. 1 (2011): 59-83.

86 Robert Kargon, Arthur Molella, Invented Edens: Techno-Cities of the Twentieth Century (Cambridge мA: мrт Press, 2008), 93; Jeffrey Schnapp, Building Fascism, Communism, Liberal Democracy: Caetano Ciocca - Architect, Inventor, Farmer, Writer, Engineer (Stanford CA: Stanford University Press, 2004), 71-100.
} 
abstracted Roman monumentality ${ }^{87}$ ), were revealing of a much more fundamental failure of the Italian rationalist architects in the 1930s to shape the dominant discursive framework in which the regime confronted choices for its future political direction. From the first moment of its publication, the team behind Quadrante had ridden the wave of Fascist corporatism, arguing vigorously for the extension of its premise of organic unity to the fields of architecture and urban planning. 'Corporatist urbanism' became the banner under which construction extended from the individual building to the entire community and city, then region, and finally the entire national territory, thereby overcoming dichotomies between different administrative regions of the country and traversing the urban-rural divide. But even more importantly, the Quadrante rationalists invested heavily in corporatism as the singular futural direction of the Fascist programmatic 'third way' - and as a final victory against competing visions that never was. In the eyes of the Quadrante mavericks, corporatist urbanism was the 'total' materialization of the corporatist doctrine, bringing every aspect of economic, social, and political life under the auspices of the Fascist state. ${ }^{88}$ By $1935^{-3}$, however, the tide had turned once again. The Fascist regime was set on a very different discursive trajectory in the mid-1930s. Giuseppe Bottai, the ideological nous and high priest of Fascist corporatism, was long gone from the ministry; his move mirrored the decline of the entire corporatist experiment as an overarching ideological and political framework for the Fascist regime. In his subsequent roles as governor of Rome and minister of education, Bottai was instrumental in formalising Fascism's discursive alignment with an idea of universality based on the timelessness of the spirit of romanità. Perhaps ironically, this same Bottai who played a very active role in convincing Mussolini about applying for the 1941 world fair that eventually resulted in the gargantuan preparations for the 'universal' expo of E42. ${ }^{89}$

Unsurprisingly, it was Piacentini who was entrusted overall responsibility for the design of the purpose-built exhibition quarter in the southern outskirts of Rome. The incontrovertible master of the Fascist architectural 'third way' put together yet another impressive display of 'aesthetic pluralism' by

87 Flavia Marcello, 'The Politics of Place: Citing and Re-Siting the Palazzo Littorio, Mussolini's New Fascist Party Headquarters in Rome,' Architectural Theory Review 12, no. 2 (2007): 146-172; Kirk, The Architecture of Modern Italy, 109-114.

88 David Rifkind, "Everything in the State, Nothing against the State, Nothing outside the State": Corporativist Urbanism and Rationalist Architecture in Fascist Italy,' Planning Perspectives 27 , no. 1 (2012): 51-80.

89 Archivio Centrale dello Stato (Rome), Carte Cini: 'Progetto Di Massima per un Esposizione Universale di Roma,' 4 (1935). 
assembling an extraordinary team of architects for the $\mathrm{E}_{42}$ plan and then inviting architects of all aesthetic persuasions to compete for a long list of signature monumental buildings. The sheer monumental scale and unitary conception of the project was the fullest, most convincing symbolic simulation of Fascism as the author of a 'third way' equilibrium - between universality and regionalism, between future and past, between radical modernity and tribute to tradition. Eventually Piacentini fell out with many of his original collaborators among them Pagano, his supposed co-author of the E42 overall regulatory plan. ${ }^{90}$ Still, his architectural 'third way' mediation between romanità and universalità proved difficult to resist even for otherwise avowed modernists. As the brief for the competition for the Palazzo dei Congressi e Ricevimenti clearly stipulated, what was sought was 'an architecture ... grounded not only on modern and functional lines but also on a classical and monumental sentiment'. The exuberant but highly idiosyncratic (not to mention its rather loose interpretation of the brief) submissions of the Terragni-Lingeri team for the same competition were praised but eventually turned down in favour of Adalbert Libera's more complaisant interpretation of the brief. Libera, the erstwhile head of MIAR, was awarded the first prize on condition that he would revise his plan by introducing more and more classical elements - like more dense pillars on one of the facades - that strengthened the building's 'Roman' legibility. ${ }^{91}$ Other modernist architects did thrive in the $\mathrm{E}_{42}$ competitions. The competition for the monumental entrance to the E42 quarter, the Piazza Imperiale, concluded with two winning projects, one by Luigi Moretti and the other by the well-established partnership between Francesco Fariello, Saverio Muratori, and Ludovico Quaroni. On the opposite end of the E42 monumental axis, the commission for the edifices surrounding the Piazza delle Forze Armate was awarded jointly to Mario De Renzi (together with Libera, designer of the famous facade for the 1937 Exhibition of the Fascist Revolution) and Gino Pollini (ex-member of the rationalist Gruppo 7 and collaborator of prominent rationalists, such as Terragni). ${ }^{92}$ Another team headed by Pietro Aschieri was entrusted with the responsibility for the buildings framing the Piazza della Romanità, including the future permanent home of the 1937 Augustan Exhibition of Romanità (Mostra Augustea della Romanità) that had marked the $2000^{\text {th }}$ year anniversary from the birth of emperor Augustus and never shied away

\footnotetext{
9o Alessandra Muntoni, Roma tra le due Guerre: Architettura, modelli urbani, linguaggi della modernità (Rome: Kappa, 2010), 176-177.

91 Francesco Garofalo, Luca Veresane, Adalberto Libera (New York: Princeton Architectural Press, 2002), 99-106.

$92 \quad$ Architettura 17 (1938): 885-905.
} 


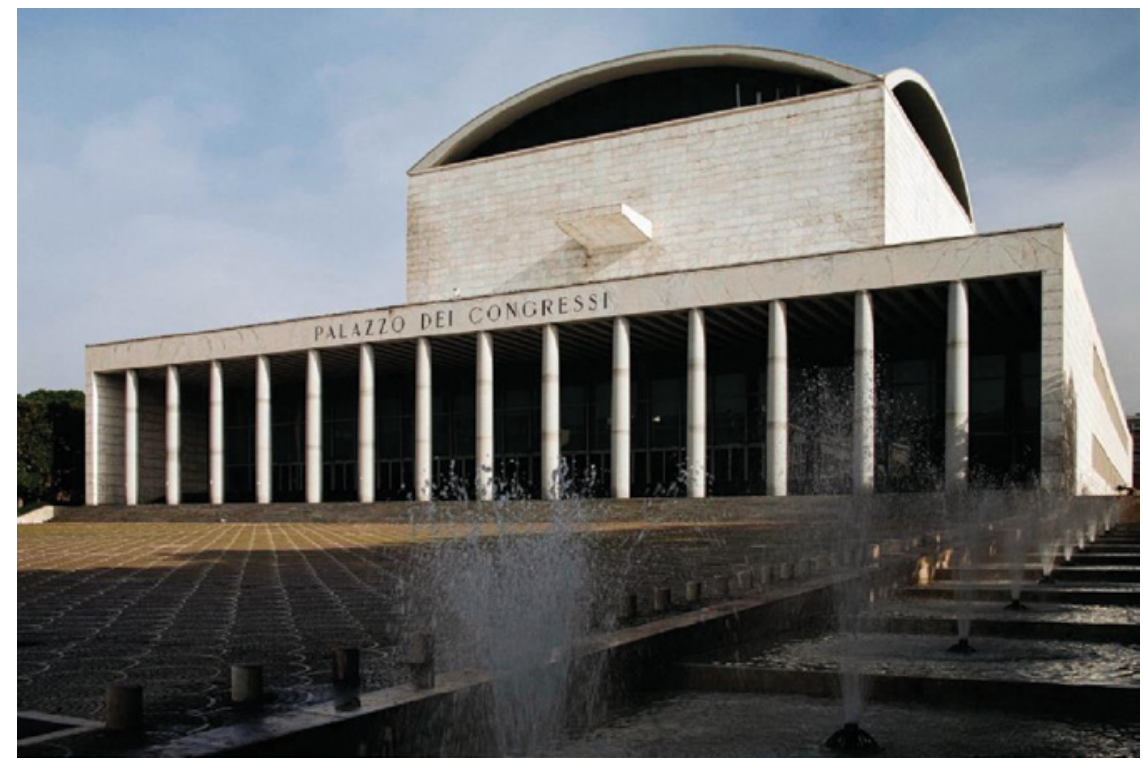

Figure 8 Palazzo dei Congressi e dei Ricevimenti, E42, 1938-54 (arch. Adalberto Libera). SOURCE: ARISTOTLE KALLIS

from using the occasion to establish a direct historical link between him and Mussolini. ${ }^{93}$ Gaetano Minnucci (another former member of MIAR) received the commission to build the main office complex of the E42. Unity of style and equilibrium between a modern monumentality and a tribute to the tradition of romanità set the tone of the entire $\mathrm{E}_{42}$ quarter. Any architect who was willing to subscribe to this spirit of 'third way' mediation, of a fusion of Fascist universality situated in the myths of Rome, avoiding excesses and intransigent positions, would be rewarded, one way or another.

The вв PR team of young rationalists that had grown in stature from the pages of Quadrante chose to compete for the other major competition of the E42 quarter - the Palazzo della Civiltà Italiana. Their submission was based

93 On the 1937 Mostra Augustea della Romanità exhibition see Silverio Liberati, 'La Mostra Augustea della Romanità : l'allestimento della facciata, il progetto e l'organizzazione delle sale, il consuntivo della manifestazione, l'eredità,' in Il Palazzo delle Esposizioni: urbanistica e architettura, ed. R. Siligato, M. Tittoni and M. Riposati (Rome: Carte Segrete, 1990), 223-227; F. Scriba, Augustus im Schwarzhemd? Die Mostra Augustea della Romanità in Rom 1937/38 (Frankfurt: P. Lang, 1995); F. Marcello 'Mussolini and the Idealisation of Empire: The Augustan Exhibition of Romanità,' Modern Italy 16, no. 3 (2011): 223-247; Joshua Arthurs, 'Bathing in the Spirit of Eternal Rome: The Mostra Augustea della Romanità,' in Brill's Companion to the Classics, Fascist Italy and Nazi Germany, ed. Helen Roche and Demetriou Kyriakos (Leiden: Brill, 2018), 157-177. 
on an earlier design for a museum of Italian civilization, enthusiastically supported by Massimo Bontempelli and other members of the Quadrante circle. BвPR presented the design to Mussolini back in 1935, who had endorsed it and even supported the idea of situating the museum on the monumental Via dell'Impero. ${ }^{94}$ When the idea for the exhibition was absorbed into the

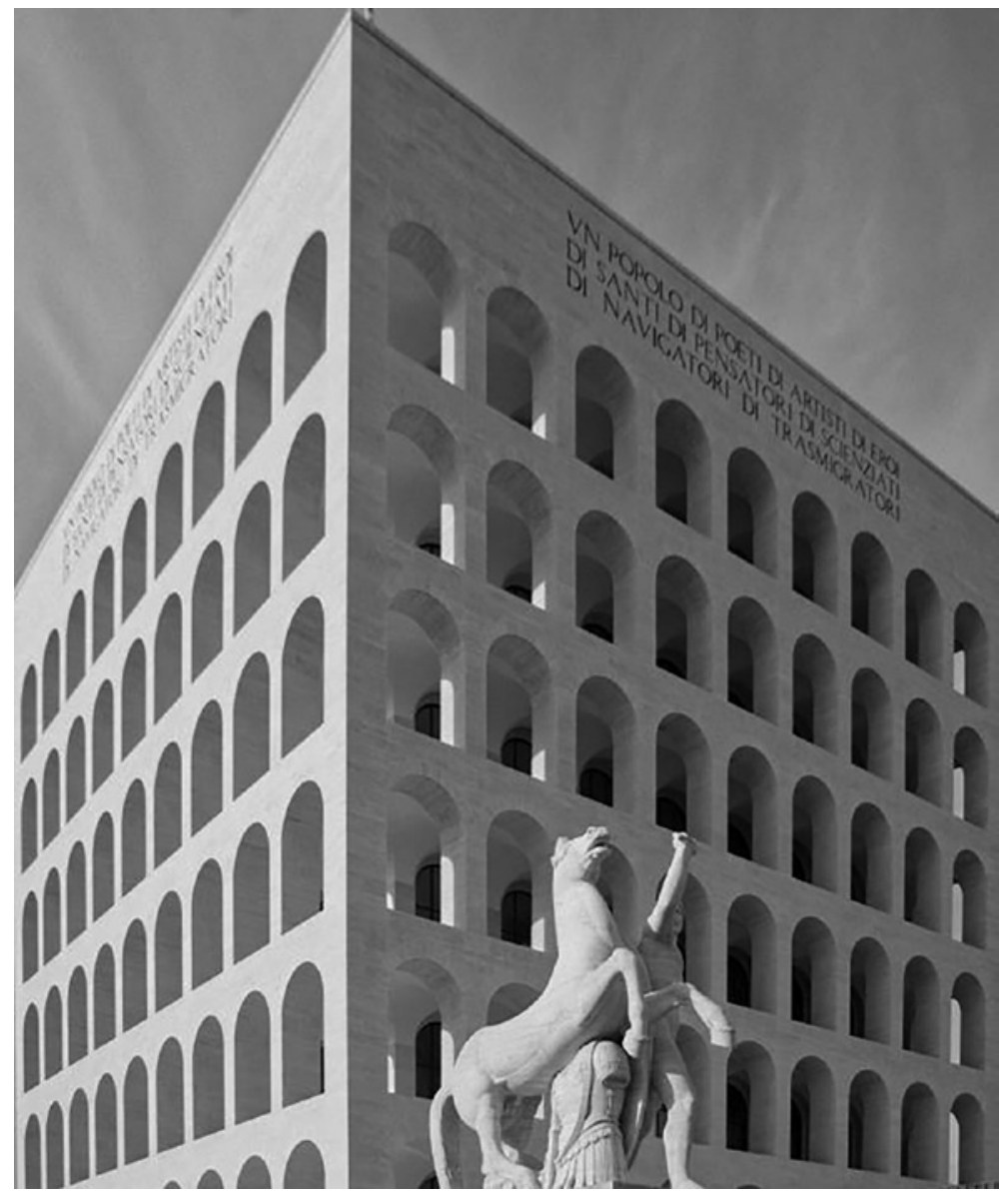

FIGURE 9 Palazzo della Civiltà Italiana, E42, 1935-40 (arch. Giovanni Guerrini, Ernesto Bruno Lapadula and Mario Romano)

94 Enrico Guidoni, 'L'E42, città della rappresentazione: Il progetto urbanistico e le polemiche sull'architettura,' in E42:. Utopia e Scenario del Regime: Urbanistica, Architettura, Arte e Decorazione, ed. Maurizio Calvesi, Enrico Guidoni and Simonetta Lux (Venice: Marsilio, 1987), 17-73, 20-22; Alessandra Muntoni, 'La vicenda dell'E42: Fondazione di una città in forma didascálica,' in Classicismo, classicism: architettura Europa/America 1920-1940, ed. Giorgio Ciucci (Milano: Electa, 1995), 135-138. 


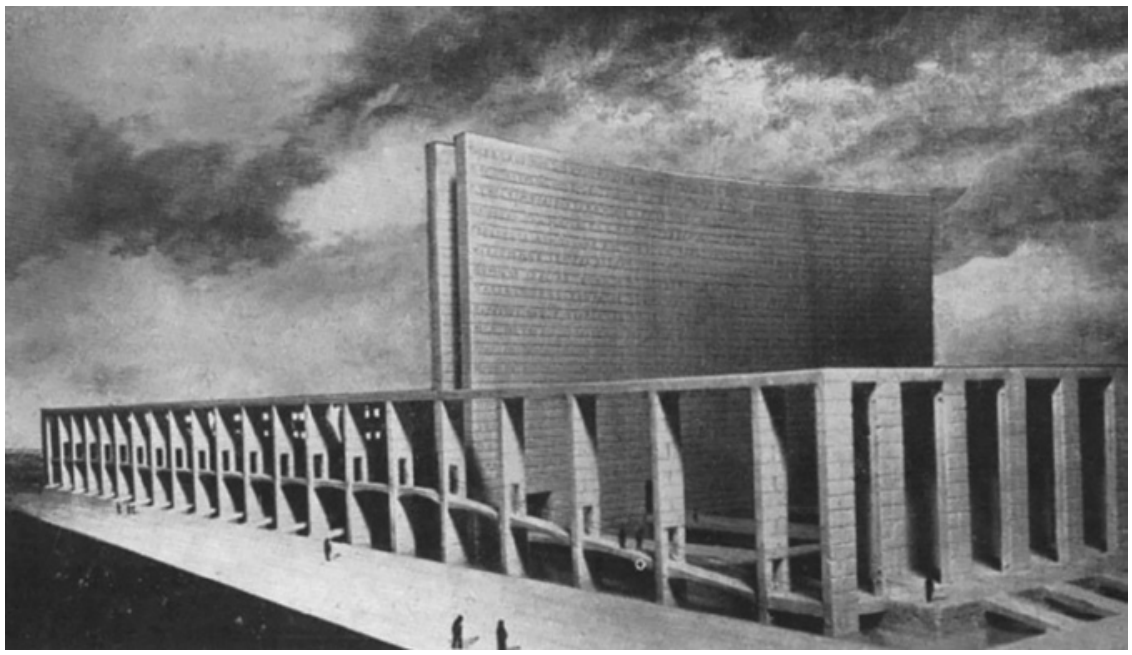

FIGURE 10

Competition entry of the BBPR group for the Palazzo della Civiltà Italiana (arch. Gianluigi Banfi, Lodovico Barbiano di Belgiojoso, Enrico Peressutti, Ernesto Nathan Rogers, Gaetano Ciocca).

SOURCE: 'CONCORSO PER IL PALAZO DELLA CIVILTÀ ITALIANA,' ARCHITETTURA, XVII, NO. 12 (1938): 853.

programme for the 1942 world fair and tied to the competition for the Palazzo della Civiltà Italiana, the BBPR partnership was invited to submit a new plan that featured a tall curved double wall framed by a monumental colonnadelike structure. The BBPR project was considered by most as the likely winner. It thus came as a surprise that the judges awarded the first prize to the submission by Ernesto Bruno La Padula, Giovanni Guerrini, and Mario Romano. Although the team had some strong modernist affinities (and La Padula had been a prominent member of MIAR in the early-1930s), the winning design was heavily criticized for its over-reliance on rhythmic arches that referenced (or, as some would say, plagiarised) the outer design of the Colosseo. A simple, yet gigantic cube with overpowering vertical lines, the winning plan passed very quickly into construction and generated fierce polemical statements from both supporters and opponents..$^{95}$ The award of the E42's post office building to the вв РR partnership immediately afterwards was little more than an inadequate consolation prize.

95 Etlin, Modernism in Italian Architecture, 498; Tim Benton, 'Humanism and fascism,' Comparative Criticism 23 (2001): 105-107. 


\section{Conclusion: Situating the 'Third Way', Universalising romanità}

In the midst of World War Two, the former secretary of CIAM Sigfried Giedion decided to take stock of the gains and notable failures of the international modernist movement in the 1930s. Looking back, he understood conceptually why modernism shunned the monument as a reaction to a 'hundred years [of] devaluation of monumentality' by historicist architecture. In hindsight, however, he came to the conclusion that this was a grave mistake of judgement: 'The people want buildings representing their social, ceremonial, and community life. They want their buildings to be more than a functional fulfilment. They seek expression of their aspirations for monumentality, for joy and excitement. 96

From the point of view of bold creativity and innovation, the $\mathrm{E}_{42}$ quarter appeared then (and continues to be regarded by many architectural historians ${ }^{97}$ ) as a frustratingly retrograde leap - and an excruciating defeat for the aspirations that had set the Italian rationalist movement ablaze back in the late-1920s and early-1930s. Pagano disparaged the work as a 'memorial (built) from travertino (marble)' that 'monumentalizes emptiness ... [and shows] decadence of taste, poverty of imagination, incapacity of architectural judgement by those "authoritative" figures; the false, useless, most clumsy columns. ${ }^{98}$ Such a judgement misses, however, a critical point about the political and cultural horizon in which the 1942 world exhibition project took shape. The E42 quarter was intended as the most complete in symbolic power and monumental in scale simulation of a perfectly 'situated' Fascist universality; a universality that was Roman and global, traditional and futural, rooted in its surrounding space but at the same time through it referencing a timeless quality that transcended dichotomies of past and future. This was the kind of equilibrium that rationalists understood in discursive terms, but betrayed with their intransigent militancy and scarce ability for programmatic flexibility. For most rationalists, the challenge was interpreted as a project for 'romanising' the contemporary as universal, discursively rather than aesthetically, in order to justify their claim

\footnotetext{
96 Giedion, 'Nine Points,' 2-3.

97 See for example the criticism of Giorgio Ciucci, 'The Classicism of the E42: Between Modernity and Tradition,' Assemblage 8 (1989): 79-87. For a balanced view of the legacy of the E42 quarter see Kirk, The Architecture of Modern Italy, 133-137.

98 Giuseppe Pagano, 'Potremo salvarci dalle false tradizioni e dalle ossessioni monumentali?,' Casabella, 157 (1941): 2-7; cf. his articles 'Le occasioni perdute,' Casabella 158: 1-7; and 'Parliamo un po' di esposizioni,' Casabella, 159-160: 2-4.
} 
to being the sole authentic visionaries and standard bearers of the Fascist 'third way' future.

By contrast, the Piacentinian fluid, plural, flexible mediation between modernism, classical tradition, and Italian context constituted an infinitely more intelligible and legible hands-on simulation of a Fascist 'third way' utopian state of organic unity, critical historical continuity, and universalist ambition. His trademark style became a kind of 'universalising' the spirit of romanità, not just alluded to discursively but performed programmatically, 'situated' in its cultural and physical environment, experienced as a fluent new tradition. Piacentini rejected the accusations that he was an enemy of modernist architecture. In doing so, he was far from disingenuous. For he saw his role as curating a hegemonic style of official architecture for the Fascist regime that would absorb critically and 'tame' the avant-garde spirit of architectural modernism while also waging a successful defence of modern architecture against historicist critiques from cultural conservatives. For him, the happy ending would be an architecture of permanence and serene monumentality that would 'represent with clarity and dignity the spirit of our [Fascist] epoch' ad infinitum. ${ }^{99}$ In this political sense, the unadorned, repetitive arches of La Padula's Palazzo della Civiltà Italiana and the symmetrical columns that Libera tolerated on his winning Palazzo dei Ricevimenti e Congressi were far more usable markers of a modern spirit that was 'situated' temporally, spatially, culturally, and historically while also announcing confidently a Fascist future of universal political and cultural hegemony. It was an aesthetically mature form of rooted modernism that captured the unique temporality of the Third Rome and expressed in built form the transition to the new civilization that had been announced by Mussolini in 1933.100

Meanwhile, the rationalists watched with mounting irascibility as commissions for iconic monumental buildings ebbed away in the second half of the 1930s. While one should admire their dogged adherence to the programmatic rupture with historicism and their total ideological embrace of corporatism, it

99 Marcello Piacentini, 'Il concorso nazionale per il progetto del Palazzo del Littorio e della Mostra della Rivoluzione fascista in via dell'Impero,' Architettura. Fascicolo Speziale: Concorso per il Palazzo del Littorio 13, no. 12 (1934): 3; Claudia Lazzaro, 'Forging a visible Fascist nation: Strategies for Fusing Past and Present,' in Donatello Among the Blackshirts: History and Modernity in the Visual Culture of Fascist Italy, ed. Claudia Lazzarro and Roger Crum (Ithaca NY: Cornell University Press, 2005), 30-31.

100 Benito Mussolini, 'Fra due civiltà' [Between two civilizations], article published in the us journal Universal Service (1933), in Il Popolo d'Italia, No. 198, 22 Aug. 1933, and in E. and D. Susmel, ed., Omnia Opera di Benito Mussolini (Florence: La Fenice, 1951-81), XXVI, 44-45. 
is also true that the relevance of the rationalists' futural vision disintegrated as the discursive terrain of the Fascist regime shifted decisively during the same period. Back in 1931, Bardi seemed to understand the critical importance of this link - that, in order to anoint rationalism as the art of the Fascist state, rationalists had first to fight hard, against many and formidable rivals, to first win the discursive competition for defining what lay(or should lie) beyond Fascism's horizon of experience, rupture, and radical synthesis. Yet their programmatic vision kept narrowing down, excluding and alienating, unwilling to mediate or convince, and thus increasingly distant not just from the past but also from the unfolding (Fascist) present. It was not so much their style that was sidelined in the 1930s; it was rather the kind of 'third way' vision and programme they had to submit to the Mussolinian ambition for a universal 'Fascist century'. It was not just their aesthetic language that diverged from the official stile littorio eventually adopted by the regime; it was also their Fascism that pulled further and further apart from the discourse and praxis of the regime during its second, final decade. 